\author{
UNIVERSIDADE DE SÃO PAULO \\ FACULDADE DE CIÊNCIAS FARMACÊUTICAS \\ Programa de Pós-Graduação em Tecnologia Bioquímico-Farmacêutica \\ Área de Tecnologia da Fermentação
}

\title{
EFEITO DA LIOFILIZAÇÃO SOBRE A ESTRUTURA E MUDANÇAS DE FASE DA ALBUMINA BOVINA MODIFICADA POR REAÇÃO COM METOXI - POLIETILENOGLICOL
}

\author{
VIRGILIO TATTINI JUNIOR
}

\author{
Dissertação para obtenção do título de \\ MESTRE \\ Orientador: \\ Prof. Dr. Ronaldo Nogueira de Moraes Pitombo
}

São Paulo

2004 
UNIVERSIDADE DE SÃO PAULO

FACULDADE DE CIÊNCIAS FARMACÊUTICAS

Programa de Pós-Graduação em Tecnologia Bioquímico-Farmacêutica

Área de Tecnologia da Fermentação

\section{EFEITO DA LIOFILIZAÇÃO SOBRE A ESTRUTURA E MUDANÇAS DE FASE DA ALBUMINA BOVINA MODIFICADA POR REAÇÃO COM METOXI - POLIETILENOGLICOL}

VIRGILIO TATTINI JUNIOR

Dissertação para obtenção do título de MESTRE

Orientador:

Prof. Dr. Ronaldo Nogueira de Moraes Pitombo

São Paulo

2004 


\section{VIRGILIO TATTINI JUNIOR}

Efeito da liofilização sobre a estrutura e mudanças de fase da albumina bovina modificada por reação com metoxi-polietilenoglicol

Comissão Julgadora

Dissertação para obtenção do título de MESTRE

Prof. Dr. Ronaldo Nogueira de Moraes Pitombo

Orientador/Presidente

Prof. Dr. Valdir Augusto Neves

Examinador 1

Prof. Dr. Bronislaw Polakiewicz

Examinador 2

São Paulo, 02 de Abril de 2004. 
Dedico este trabalho aos meus pais

e as minhas irmãs 


\section{AGRADECIMENTOS}

Ao Prof. Dr. Ronaldo N. M. Pitombo, que como cientista, orientador e amigo, tornou possível a realização deste trabalho.

Ao Departamento de Tecnologia Bioquímico-Farmacêutica da Faculdade de Ciências Farmacêuticas da Universidade de São Paulo.

Aos Professores: Dr. Bronislaw Polakiewicz e Dr. José Abrahão Neto, pelo apoio e colaboração nas reações de PEGuilação da albumina bovina.

A Prof. Dra. Duclerc Fernandes Parra e ao químico e amigo Edson Ghilardi, pelo apoio e colaboração nas analise térmicas durante a realização da parte experimental do meu trabalho.

Ao Prof. Dr. Reinaldo Guidici e ao Dr. Marlon Martins dos Reis, pelo valioso auxílio nas análises de espectroscopia Raman.

Aos professores, funcionários e colegas do Departamento de Tecnologia Bioquímico-Farmacêutica, pela constante demonstração de carinho e amizade.

À Dra. Kati Vannucci Chaim pelo constante apoio e incentivo no campo da liofilização na indústria farmacêutica.

Aos funcionários do setor de liofilização da Eurofarma Laboratórios: Nilson, André, João, Aparecido, Francisco e Luis, pelo valioso ensino prático sobre liofilização.

Aos meus familiares pela constante motivação nestes anos.

Enfim, a todos que direta ou indiretamente contribuíram para a realização deste trabalho. 
"Na medida em que a água é tão comumente encontrada e utilizada em diversas situações, os homens se tornaram aptos a imaginar que eles entendem por completo a sua natureza. Porém todos aqueles que cuidadosamente se aplicaram em compreendê-la, depararam-se com um dos assuntos mais difíceis de serem entendidos, dentre as filosofias naturais" Herman Boerhave (século XVIII) 


\section{SUMÁRIO}

RESUMO

ABSTRACT

1. INTRODUÇÃO 1

1.1. Modificação química de proteínas 1

1.1.1. Propriedades do polietilenoglicol (PEG) 3

1.1.2. Succinimidil PEG 4

1.2. Estabilidade protéica $\quad 5$

1.2.1. A albumina bovina 6

1.3. Liofilização 6

1.3.1. Congelamento: a primeira etapa na liofilização 7

1.4. DSC, temperatura de transição vítrea e estabilidade da proteína 12

1.5. Espectroscopia Raman 15

1.6. Umidade residual 20

2. OBJETIVO 23

3. MATERIAIS E MÉTODOS 23

$\begin{array}{ll}3.1 \text { Materiais } & 23\end{array}$

$\begin{array}{ll}\text { 3.2. Métodos } & 23\end{array}$ 
3.2.2. Determinação da temperatura de transição vítrea

3.2.3. Análise estrutural

3.2.4. Determinação do teor de umidade residual

3.2.5. Liofilização da albumina bovina nativa

3.2.6 Síntese do metoxi-poietilenoglicol 5000

3.2.7. Preparação da solução de albumina bovina modificada com metoxi-PEG 26

3.2.8. Liofilização da albumina bovina modificada com metoxi-polietilenoglicol 


\section{RESUMO}

A conjugação por polietilenoglicol (PEG) mascara a superfície das proteínas e aumenta o tamanho molecular do polipeptídio, reduzindo assim sua ultrafiltragem renal, impedindo a aproximação de células processadoras de antígenos ou anticorpos e reduzindo a degradação por enzimas proteolíticas. 0 PEG transfere para as moléculas suas propriedades físico-químicas e, conseqüentemente, modifica também a biodistribuição e a solubilidade de drogas peptídicas e não peptídicas. As soluções de proteínas são facilmente desnaturadas (muitas vezes irreversivelmente) pelo aparecimento de numerosos eventos que podem afetar a estabilidade das soluções, tais como: aquecimento, agitação, congelamento, mudanças no pH e exposição a interfaces ou agentes desnaturantes, resultando geralmente na perda da eficácia clínica e aumento do risco de efeitos colaterais adversos. A solução prática para o dilema da estabilidade da proteína é a remoção da água. A liofilização é o método mais comumente utilizado para a preparação de proteínas desidratadas, as quais, teoricamente, devem apresentar uma estabilidade adequada por um longo período de armazenagem em temperaturas ambientes. A proteína utilizada neste estudo foi a albumina sérica bovina (BSA), amplamente estudada no campo da bioquímica. Através da espectroscopia Raman associada com análise térmica por DSC, análise colorimétrica, e a determinação do teor de umidade, verificou-se que o congelamento rápido $\left(30{ }^{\circ} \mathrm{C} / \mathrm{min}\right.$.) favoreceu a manutenção da estrutura conformacional da proteína após a liofilização, porém aumentou o tempo de secagem primária em sete horas em relação ao congelamento lento $\left(2,5^{\circ} \mathrm{C} / \mathrm{min}\right.$.). Após a modificação da albumina bovina por reação com o metoxi-PEG verificou-se

que a BSA-PEG $(1: 0,25)$ apresentou um menor grau de alteração estrutural e conseqüentemente uma menor variação das características físico-químicas, além de otimizar as condições de liofilização e armazenamento da proteína quando comparada com a BSA-PEG $(1: 0,5)$.

Palavras chaves: liofilização, modificação de proteínas, espectroscopia Raman, análise térmica, albumina bovina. 


\section{ABSTRACT}

PEG conjugation masks the protein's surface and increases the molecular size of the polypeptide, thus reducing its renal ultrafiltration, preventing the approach of antibodies or antigen processing cells and reducing the degradation by proteolytic enzymes. The PEG conveys to molecules its physicochemical properties and therefore modifies also biodistribution and solubility of peptide and non-peptide drugs. This property opens new techniques in biocatalysis and in pharmaceutical technology where many insoluble drugs are solubilized by PEG conjugation and thus more easily administered. Aqueous protein solutions are readily denatured (often irreversibly) by numerous stresses arising in solution, e.g., heating, agitation, freezing, $\mathrm{pH}$ changes, and exposure to interfaces or denaturants, usually resulting in lost of clinical efficacy and increase the risk of adverse side effects. Even if its physical stability is maintained, a protein can be degraded by chemical reactions (e.g., hydrolysis and deamidation), many of which are mediated by water. The practical solution to the protein stability dilemma is to remove the water. Lyophilization is most commonly used to prepare dehydrated proteins, which, theorecally, should have the desired long-term stability at ambient temperatures. The protein used in this study was the bovine serum albumin (BSA), largely studied in the biochemical field. Through Raman spectroscopy associated with thermal analysis using DSC, Colorimetric analysis and the determination of water content It was observed that the fast freezing $\left(30{ }^{\circ} \mathrm{C} / \mathrm{min}\right.$.) favored the maintenance of the conformational structure in the protein after lyophilization, however increased the primary drying in seven hours with regard to the slow freezing $\left(2,5{ }^{\circ} \mathrm{C} / \mathrm{min}\right.$.). After the modification of bovine serum albumin with methoxy-PEG it was observed that the BSA-PEG $(1: 0,25)$ showed a lower degree of structural alterations and consequently a lower variation on the physicalchemical characteristics, moreover optimized the conditions during the lyophilization process and storage of the protein when it was compared to BSAPEG (1:0,5). 


\section{INTRODUÇÃO}

\subsection{Modificação química de proteínas}

No final dos anos 50, a modificação química de proteínas tornou-se uma prática comum e foram desenvolvidas técnicas para facilitar a análise das relações entre estrutura e atividade das moléculas de proteína. Existem resíduos de aminoácidos com diferentes reatividades em uma proteína, dependendo de sua localização na estrutura da proteína nativa. Alguns estão ocultos no interior da molécula de proteína e outros estão expostos na superfície. Outras condições locais, tais como ligação com hidrogênio e ligação iônica entre cadeias laterais de aminoácidos, diferenciam seus estados mais adiante. Para testar os diferentes estados dos resíduos de aminoácidos em proteínas, foram explorados reagentes de modificação química. A finalidade de tais modificações era investigar os estados físico-químicos de vários resíduos de aminoácidos e identificar os aminoácidos envolvidos na função de uma proteína específica (Kodera et. al., 1998).

Desde 1970 foram publicados diversos artigos referentes à modificação química das proteínas pela conjugação com macromoléculas sintéticas, que são derivadas do polietilenoglicol (PEG) (Kodera et.al.,1998). Os objetivos destas modificações protéicas incluíram a redução da imunoreatividade ou da imunogenicidade e a supressão da produção de imunoglobulina E. Em 1977, Davis e seus colegas demonstraram que a ligação covalente do PEG com a albumina sérica e a catalase promoveu a redução da imunoreatividade para os respectivos anticorpos (Kodera et. al., 1998).

A relação entre imunoreatividade e grau de modificação obtido pela conjugação da BSA e da asparaginase com o PEG pode ser observada na tabela 1 (Inada et. al., 1995). Características não-imunogênicas e aumento do tempo de circulação da droga modificada com o PEG foram demostradas pelos mesmo pesquisadores, que conjugando o PEG com a L-asparaginase (P.M. 136,000 Da) proveniente da E.coli, usada como enzima na terapia anticâncer (leucemia e linfosarcoma). Esta mesma enzima foi desenvolvida clinicamente e passou a ser comercializada pela empresa ENZON, pelo nome comercial de Oncaspar $^{R}$ (Greenwald, 2001). 
Tabela 1. Relação entre atividade, imunoreatividade e grau de modificação obtido pela conjugação da BSA e da asparaginase com derivados de PEG

\begin{tabular}{|c|c|c|c|}
\hline $\begin{array}{l}\text { Reagente } \\
\text { modificado }\end{array}$ & $\begin{array}{l}\text { Peso molecular } \\
\text { (Da) }\end{array}$ & $\begin{array}{c}\text { Grau de modificação } \\
(\%)\end{array}$ & $\begin{array}{c}\text { Imunoreatividade } \\
(\%)\end{array}$ \\
\hline $\begin{array}{l}\text { Albumina bovina } \\
\text { (BSA) sem } \\
\text { modificação }\end{array}$ & 66,210 & $0(0)^{a}$ & 100 \\
\hline $\begin{array}{c}\text { Conjugada com } \\
\text { PEG }_{1}\end{array}$ & 5000 & $42(25)$ & 0 \\
\hline $\begin{array}{c}\text { Conjugada com } \\
\mathrm{PEG}_{2}\end{array}$ & 10,000 & $25(15)$ & 0 \\
\hline $\begin{array}{c}\text { Conjugada com } \\
\text { PM }_{13}\end{array}$ & 13,000 & $30(18)$ & 0 \\
\hline $\begin{array}{c}\text { Conjugada com } \\
\text { PM }_{100} \\
\end{array}$ & 100,000 & $20(12)$ & 0 \\
\hline $\begin{array}{c}\text { Asparaginase } \\
\text { sem modificação }\end{array}$ & 136,000 & $0(0)$ & 100 \\
\hline $\begin{array}{c}\text { Conjugada com } \\
\text { PEG }_{1}\end{array}$ & 5000 & $79(73)$ & 0 \\
\hline $\begin{array}{c}\text { Conjugada com } \\
\text { PEG }_{2}\end{array}$ & 10,000 & $57(73)$ & 0 \\
\hline $\begin{array}{c}\text { Conjugada com } \\
\text { PM }_{13}\end{array}$ & 13,000 & $50(46)$ & 0 \\
\hline $\begin{array}{c}\text { Conjugada com } \\
\text { PM } 100\end{array}$ & 100,000 & $34(31)$ & 0 \\
\hline
\end{tabular}

a Parênteses: número de grupos aminas ligadas a cada reagente modificado. Números totais de grupos aminas na molécula de BSA e da asparaginase são de 60 e 92 , respectivamente.

PM: copolímero do PEG (polietilenoglicol) (Kodera et al.,1998).

Provavelmente, uma das características mais marcantes da modificação molecular usando o PEG é o aumento da meia-vida $\left(T_{1 / 2}\right)$ e da concentração das proteínas terapêuticas no plasma sanguíneo. Estas características podem ser atribuídas, em parte, pelo aumento do peso molecular da molécula conjugada com o PEG, alterando o sistema de filtração renal e também pela redução da proteólise enzimática (Greenwald, 2001).

A adenosina-deaminase (ADA) conjugada com o PEG (PEG-ADA) (Levy,Y,et al., 1988) foi em 1991 a primeira conjugação PEG-proteína a ser aprovada pelo FDA (Food and Drugs Administration). Esta droga é usada no 
tratamento de crianças que apresentam severa deficiência de ADA combinada com imunodeficiência.

Mais de 40 proteínas foram modificadas com o PEG ou derivados de PEG para uso terapêutico.

Sehon e colaboradores (1991) relataram que a formação dos anticorpos classe IgE causada pelo pólen alergênico da erva-de-santiago é suprimida pela administração do PEG alergênico.

Uma abordagem nos processos biotecnológicos é preparar enzimas modificadas com PEG que possuam tanto propriedades hidrofílicas como hidrofóbicas (Inada et. al., 1986). As enzimas modificadas, tais como a peroxidase, catalase, lípase e quimiotripsina, são todas solúveis e ativas em solventes orgânicos. Enzimas hidrolíticas modificadas catalisaram a reação reversa da hidrólise nos solventes orgânicos (Kodera et. al., 1998). Estes achados abriram um novo caminho no desenvolvimento dos processos biomédicos e biotecnológicos. Este conceito foi aplicado não somente em proteínas e enzimas, mas também às substâncias bioativas tais como hemina, melanina e clorofila.

\subsubsection{Propriedades do polietilenoglicol (PEG)}

Os polietilenoglicóis apresentam comportamento anfipático, solúveis em água, tolueno, 1,1,1- tricloroetano e benzeno, e insolúveis em éter etílico e hidrocarbonetos alifáticos. Não apresentam toxicidade (P.M. >1.000). O polietileno glicol (P.M. $=4.000)$ pode ser administrado com segurança, por via endovenosa, em soluções a $10 \%$ em ratos, cobaias, coelhos e macacos e em uma dose de 16 $\mathrm{g} / \mathrm{kg}$ de peso corporal (a aprovação do FDA foi concedida para uso interno) (Kodera et. al., 1998). Possuem baixa imunogenicidade, causam fusão celular (em altas concentrações), formam sistemas bifásicos com uma solução aquosa de outras macromoléculas tais como o dextran ou soluções salinas concentradas e podem ser usados para precipitar proteínas e ácidos nucléicos.

Se o PEG é ligado covalentemente com proteínas, a conjugação pode exibir as seguintes propriedades:

- solubilização de enzimas e substâncias bioativas em solventes orgânicos ou em soluções aquosas;

- tornar proteínas não imunogênicas; 
- prolongar o tempo de liberação da droga proteína PEG in vivo;

- estabilizar a função fisiológica de proteínas e substâncias bioativas;

- modificar a farmacocinética de várias drogas;

- separar macromoléculas biológicas, membranas, partículas celulares e células.

O polietilenoglicol (PEG), cuja fórmula geral é :

$$
\mathrm{HO}-\left(\mathrm{CH}_{2} \mathrm{CH}_{2} \mathrm{O}_{2}\right)_{n}-\mathrm{CH}_{2} \mathrm{CH}_{2} \mathrm{OH}
$$

com pesos moleculares característicos que variam de 500 a 20.000 Daltons apresentam-se não-imunogênicos e solúveis em soluções aquosas, assim como na maioria dos solventes orgânicos. O polímero não é tóxico e não danifica proteínas ativas ou células. Apesar de sua aparente simplicidade, esta molécula desperta muito interesse nas áreas da biomedicina e da biotecnologia (Kodera et. al., 1998).

Quando o PEG é adequadamente ligado a um polipeptídio, ele modifica muitas de suas características, enquanto suas principais funções biológicas, tais como atividade enzimática ou reconhecimento do receptor, são mantidas. A conjugação por PEG mascara a superfície das proteínas e aumenta o tamanho molecular do composto, reduzindo assim sua ultrafiltragem renal, impedindo a aproximação de antígenos ou anticorpos e reduzindo a degradação da mesma por enzimas proteolíticas. Finalmente, o PEG transfere para as moléculas suas propriedades físico-químicas e, conseqüentemente, modifica também a biodistribuição e a solubilidade de drogas peptídicas e não peptídicas. Estas propriedades abrem novas técnicas na biocatálise e na tecnologia farmacêutica, onde muitas drogas insolúveis são solubilizadas através da conjugação do PEG e, dessa forma, mais facilmente administradas (Veronese et. al. 2001).

\subsubsection{Succinimidil PEG (mPEG)}

O mPEG com um grupo carboxila terminal é um derivado versátil. Pode ser usado para o preparo de ésteres ativos do polímero, assim como para ligação direta a moléculas com importância biológica. O éster N-hidroxisuccinimidil (NHS) de PEG reagirá diretamente com um grupo amina nas moléculas de proteína com o pH variando de 7.0 a 9,0. Um dos métodos mais práticos para introduzir grupos de carboxila ao grupo hidroxila de PEG pode ser a reação com anidrido succínico, 
que é ativado como succinato de succinimidil de PEG [SS-(PEG)]. Alternativamente, o carboximetil ou o PEG de carboxietil também estão disponíveis (Kodera et. al., 1998).

\subsection{Estabilidade protéica}

Existem numerosas aplicações exclusivas e importantes para as proteínas nos cuidados com a saúde humana (Carpenter et. al., 1999). Entretanto, mesmo a mais promissora e efetiva proteína terapêutica não será benéfica se sua estabilidade não for mantida durante o seu acondicionamento, transporte, armazenamento e administração. Devido a facilidade na preparação, contenção de custos e simplicidade no manuseio do produto final, as proteínas são preferencialmente preparadas na forma farmacêutica de solução aquosa. Entretanto, as soluções de proteínas são facilmente desnaturadas (muitas vezes irreversivelmente) pelo aparecimento de numerosos eventos que podem afetar a estabilidade das soluções, tais como: aquecimento, agitação, congelamento, mudanças no pH e exposição a interfaces ou agentes desnaturantes, resultando geralmente na perda da eficácia clínica e aumento do risco de efeitos colaterais adversos. Mesmo se a estabilidade física for mantida, uma proteína pode ser degradada por reações químicas, como por exemplo, hidrólise e deamidação, muitas das quais são mediadas pela água. Assim, a instabilidade inerente da proteína e/ou a logística do manuseio do produto geralmente impedem o desenvolvimento das fórmulas líquidas. Além disso, a mera preparação de produtos congelados estáveis, o que é relativamente simples, não é uma alternativa prática, devido ao fato de que as condições necessárias de transporte e armazenamento não são tecnicamente e/ou economicamente viáveis em muitos mercados (Carpenter et. al., 1999) .

A solução prática para o dilema da estabilidade da proteína é a remoção da água. 


\subsubsection{A albumina bovina}

A proteína utilizada neste estudo foi a albumina sérica bovina (BSA), amplamente estudada no campo da bioquímica. A BSA é a proteína mais abundante no plasma sanguíneo e serve como depósito, assim como transporte de proteína para numerosos componentes, como cadeia longa de ácidos graxos ou bilirrubina, ligados a uma alta afinidade à proteína. A estrutura secundária da albumina bovina contém muitos resíduos de cistina e são helicoidais em grande parte da cadeia. Apresenta fácil isolamento em grandes quantidades favorecendo sua alta estabilidade e solubilidade. É a principal proteína que contribui para a pressão coloidal osmótica do sangue e também para o transporte de proteína para numerosos compostos endógenos e exógenos. Com uma massa molecular de $66 \mathrm{kDa}$, consiste em uma única cadeia polipeptídica, contendo cerca de 580 aminoácidos (Nakamura et. al., 1997). A albumina bovina (BSA) passa por notáveis mudanças reversíveis na conformação, usualmente sob condições não fisiológicas.

\subsection{Liofilização}

A liofilização é o método mais comumente utilizado para a preparação de proteínas desidratadas, as quais, teoricamente, devem apresentar uma estabilidade adequada por um longo período de armazenagem em temperaturas ambientes. A liofilização é um processo de secagem constituído de três etapas : congelamento, secagem primária e secagem secundária. O material, previamente congelado, é desidratado por sublimação, utilizando-se baixas temperaturas de secagem a pressões reduzidas. A liofilização é o método de primeira escolha para produtos termolábeis. Entretanto, estudos recentes com espectroscopia por infravermelho têm documentado que os problemas relacionados com o congelamento e a desidratação induzidos pela liofilização podem levar ao desdobramento molecular da proteína. O desdobramento não somente pode levar à desnaturação irreversível da proteína, mesmo se a amostra é reidratada imediatamente, mas também pode reduzir a estabilidade durante 0 armazenamento da proteína liofilizada (Carpenter et. al., 1999). 
Além do mais, a simples obtenção de uma proteína com conformação estrutural nativa em amostras reidratadas imediatamente após a liofilização não é necessariamente indicativo de estabilização adequada durante a liofilização ou armazenamento. Muitas proteínas apresentam desdobramento estrutural durante a liofilização, mas logo são restauradas se hidratadas imediatamente (Carpenter et. al., 1999) .

As proteínas raramente podem ser liofilizadas sem perda da atividade, geralmente associadas à alterações em sua conformação. Portanto, um agente estabilizante, por exemplo, um açúcar ou um poli-álcool, normalmente é exigido. A adição de um estabilizador, normalmente em uma concentração muito mais alta que a da própria proteína, resulta em uma transição vítrea predominantemente observada durante o resfriamento ou desidratação (Wang, 2000).

\subsubsection{Congelamento : a primeira etapa na liofilização}

A finalidade do congelamento dentro do processo de liofilização consiste na imobilização do produto a ser liofilizado, interrompendo reações químicas e atividades biológicas.

A estrutura do produto, o tamanho e forma são determinados após o congelamento, assim como a sublimação e as características do produto final. Esta estrutura não pode ser alterada durante o processo de liofilização, porém quando se faz, ocorrem danos ou a perda do produto. O congelamento é uma das etapas mais críticas do processo de liofilização (Murgatroyd, et. al., 1997).

Uma solução verdadeira pode-se congelar por meio de dois mecanismos: com formação de eutético, solidificação no estado amorfo ou uma mistura de ambos. Ao resfriar-se uma solução diluída, inicialmente ocorre o superresfriamento da água pura seguido da nucleação e cristalização. A concentração do soluto aumentará para uma concentração crítica. A esta concentração e sob temperatura pertinente, a solução concentrada sofrerá um congelamento eutético ou uma transição vítrea (figura 1). O congelamento eutético é uma cristalização. Uma transição vítrea é um grande aumento na viscosidade do material, um sólido amorfo, que na verdade é uma solução super-congelada que conserva propriedades visco-elásticas. 


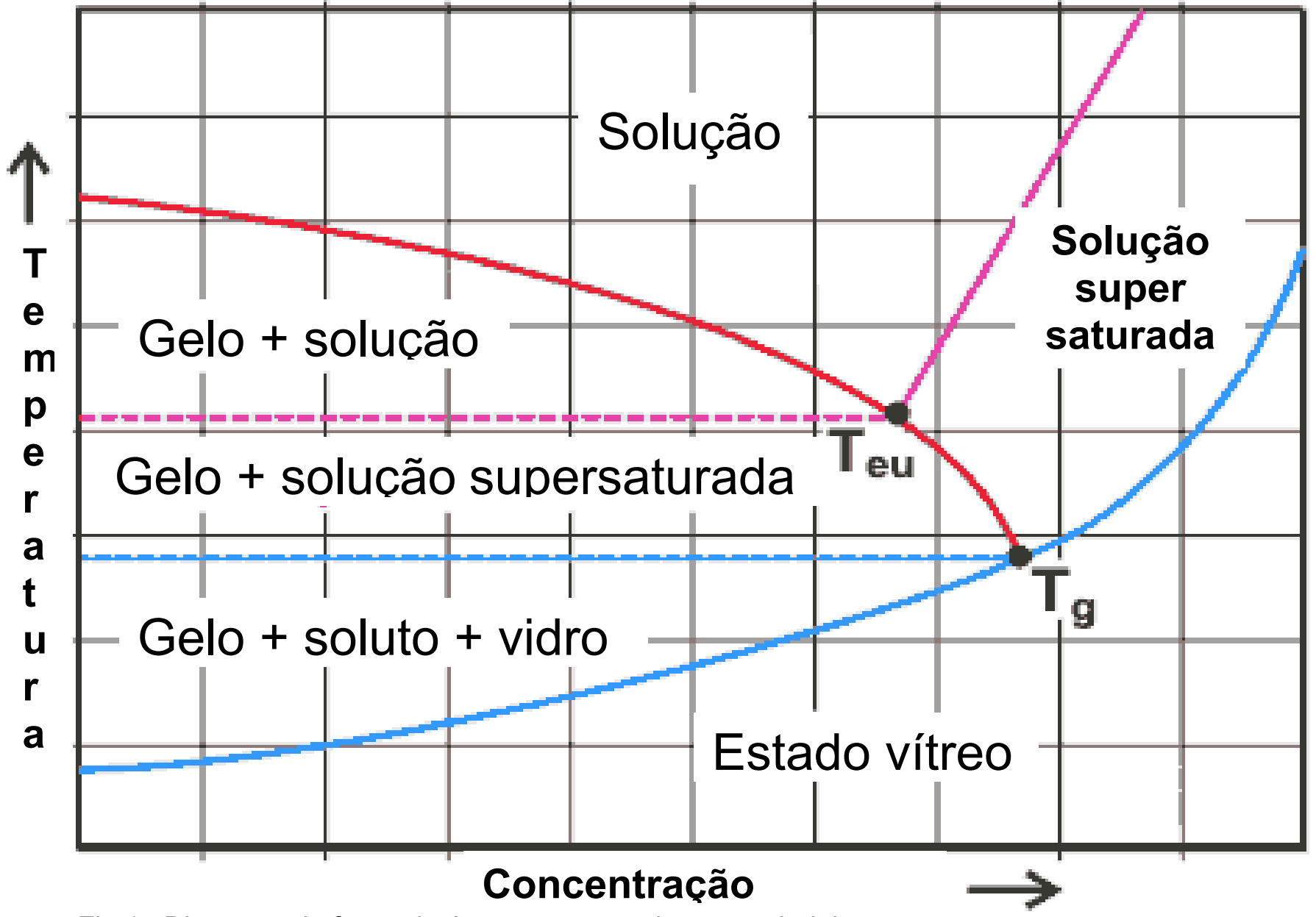

Fig.1. Diagrama de fases da água em uma solução verdadeira.

A temperatura de transição vítrea é caracterizada pelo aumento da viscosidade, onde a mobilidade molecular diminui bruscamente, impedindo a cristalização. Antes de alcançar a temperatura de transição vítrea, a mistura congelada passa por um ponto chamado temperatura de colapso, onde a viscosidade da mistura soluto / solvente é tal que ela conservará sua estrutura e forma ao longo do processo de sublimação, até mesmo quando esta não é sustentada pelo gelo dendrítico adjacente. Esta temperatura de colapso é de grande importância durante o processo de liofilização (Murgatroyd, et. al., 1997).

A estabilidade das proteínas é influenciada pelas mudanças de $\mathrm{pH}$. Durante o congelamento de soluções tamponadas, a concentração dos sais do tampão irá elevar-se, aumentando sua concentração iônica e possivelmente alterando seu $\mathrm{pH}$. Isto vai alterar o ambiente e, provavelmente, a estrutura e o nível de atividade da proteína (Wang, 2000). Muitas proteínas são estáveis apenas em uma estreita faixa de variação de $\mathrm{pH}$, como a uroquinase de baixo peso molecular (LMW-UK) em pH de 6-7. Em pHs extremos, o aumento da repulsão eletrostática entre cargas semelhantes nas proteínas tende a causar desdobramento ou desnaturação da proteína. Assim, a taxa de agregação protéica 
é fortemente afetada pelo $\mathrm{pH}$, tal como a aglutinação de interleucina $1 ß$ (IL-1ß), relaxina humana, e a Rnase A pancreática bovina. Além disso, o pH da solução pode afetar significativamente a taxa de muitas degradações químicas em proteínas (Li et al., 1995).

Os agentes tamponantes podem cristalizar seletivamente e causar mudanças de $\mathrm{pH}$ durante o congelamento. Além disso, é preferível manter todos os sais tamponantes na forma amorfa durante o congelamento das proteínas sensíveis à alterações de $\mathrm{pH}$. Uma taxa de congelamento mais rápida pode impedir a nucleação e a subseqüente cristalização. Cada sal de tampão tem sua própria taxa crítica de resfriamento, a qual é definida como a taxa mínima de resfriamento suficientemente rápido para impedir a cristalização de um soluto. A cristalização não irá ocorrer quando a taxa de congelamento superar a taxa crítica de resfriamento. Se uma solução protéica é resfriada rapidamente com nitrogênio líquido, é provável que os sais de tampão permaneçam amorfos. Por outro lado, a cristalização seletiva e a uma subseqüente mudança do pH podem ocorrer (Chang et al., 1996).

O congelamento de uma solução de proteína tamponada pode cristalizar seletivamente um tampão, causando mudanças no $\mathrm{pH}$. $\mathrm{O}$ fosfato disódico $\left(\mathrm{Na}_{2} \mathrm{HPO}_{4}\right)$ cristaliza-se mais prontamente que o fosfato monosódico $\left(\mathrm{NaH}_{2} \mathrm{PO}_{4}\right)$ porque a solubilidade da forma disódica é consideravelmente mais baixa que a da forma monosódica. Por causa disso, um tampão fosfato de sódio em pH 7 tem uma proporção molar $\left[\mathrm{NaH}_{2} \mathrm{PO}_{4}\right] /\left[\mathrm{Na}_{2} \mathrm{HPO}_{4}\right]$ de 0,72 , mas esta proporção aumenta para 57 na temperatura eutética ternária durante o congelamento. Isso pode levar a uma significativa queda de $\mathrm{pH}$ durante $\mathrm{o}$ congelamento, que então desnatura as proteínas pH-sensíveis (Franks, 1993). Por exemplo, o congelamento de uma solução da enzima Lactato Desidrogenase (LDH) causou a desnaturação da proteína devido a uma queda do $\mathrm{pH}$ de 7,5 para 4,5 pela cristalização seletiva de $\mathrm{Na}_{2} \mathrm{HPO}_{4}$. A LDH é uma proteína $\mathrm{pH}$-sensível e uma pequena queda no $\mathrm{pH}$ durante o congelamento pode desnaturar parcialmente a proteína, mesmo na presença de estabilizadores tais como a sacarose e a trealose. A queda de $\mathrm{pH}$ durante o congelamento pode também explicar por que $\mathrm{o}$ congelamento de da IgG bovina e humana em um tampão fosfato de sódio causou a formação de mais agregados do que no tampão de fosfato de potássio, pois o 
tampão de fosfato de potássio não apresenta alterações significativas de $\mathrm{pH}$ durante o congelamento (Anchordoquy et al., 1996).

A queda de $\mathrm{pH}$ durante o congelamento pode afetar potencialmente a estabilidade de armazenamento das proteínas liofilizadas. O receptor antagonista da interleucina-1 humana recombinante liofilizada (rhlL-1ra) em uma fórmula contendo tampão fosfato em pH 6,5 apresentou sinais de agregação mais rapidamente do que aquela contendo tampão de citrato no mesmo $\mathrm{pH}$ durante a armazenagem em 8,30 e $50^{\circ} \mathrm{C}$. Similarmente, a queda de $\mathrm{pH}$ de uma fórmula que continha succinato, de 5 para 3,5 durante o congelamento pareceu ser a causa da baixa estabilidade de armazenamento para o Interferon- $\gamma$ (IFN- $\gamma$ ) do que aquela contendo tampão de glicolato no mesmo pH (Lam et al., 1996).

O colapso estrutural de uma matriz liofilizada ocorre quando a viscosidade do material decresce em função do aumento da temperatura, consequentemente o material não pode se sustentar uma vez que o gelo dendrítico adjacente foi sublimado. O colapso ocorrerá, então, na interface da liofilização.

A etapa de congelamento durante a liofilização é considerada tão importante quanto à etapa de secagem, devido ao seu efeito potencial sobre as proteínas. Um parâmetro importante que precisa ser definido durante o congelamento é a taxa de resfriamento. A taxa de resfriamento pode ser definida como:

$$
v=\_\frac{\partial T(r, t)}{\partial t},
$$

onde $v$ é a taxa de resfriamento, $T(r, t)$ é o campo da temperatura, uma função tanto do tempo, $t$, como da localização, $r$. Assim, a taxa varia temporal e espacialmente. Em geral, um congelamento mais rápido gera pequenos cristais de gelo. Isso ocorre porque a água é super resfriada e a cristalização do gelo ocorre rapidamente, produzindo pequenos cristais de gelo. De modo oposto, uma taxa de resfriamento mais lenta gera cristais de gelo maiores. O tamanho dos cristais determina o tamanho do poro a ser criado durante a secagem subseqüente. Grandes cristais de gelo criam grandes poros, conduzindo a uma rápida sublimação da água durante a secagem primária, mas a secagem secundária 
pode ir mais devagar devido a superfícies de área menores, limitando a desorção da água durante a secagem secundária. Para manter um equilíbrio, tem sido recomendado um grau moderado de super-congelamento $\left(10-15^{\circ} \mathrm{C}\right)$ (Wang, 2000).

O grau de desnaturação protéica induzida pelo congelamento é uma função complexa, tanto da taxa de resfriamento como da temperatura final. $O$ efeito das taxas de resfriamento na estabilidade das proteínas varia de forma significativa. Por exemplo, o aumento da taxa de congelamento de 0,5 para $50^{\circ} \mathrm{C}$ $\min ^{-1}$ não afetou significativamente a formação de agregados solúveis de hormônio do crescimento recombinante ( $\mathrm{rGH}$ ) em $2 \mathrm{mg} \mathrm{ml}^{-1}$ e em $5 \mathrm{mM}$ de tampão fosfato (pH 7,4 ou 7,8), mas a formação de agregados insolúveis (particulados) aumentou severamente com o aumento das taxas de congelamento, mesmo na presença de mais de $250 \mathrm{mM}$ de manitol (Eckhardt et al., 1991). O congelamento rápido também causou a formação de mais agregados para a lgG bovino e humano do que o congelamento lento. Isto pode ser resultado da formação de cristais de gelo menores e de maiores interfaces de gelo/água em taxas de congelamento mais altas, levando a uma maior extensão de desnaturação da proteína induzida pela superfície. Ao contrário, o congelamento mais rápido causou menos perda da atividade da enzima Lactato Desidrogenase (LDH) e menor mudança na estrutura secundária da hemoglobina em uma solução de PEG / dextran. A perda menor da atividade protéica ocorre provavelmente porque o congelamento mais rápido pode impedir o crescimento abrangente do cristal, retardando substancialmente a desnaturação protéica frente a crioconcentração induzida da solução. Além disso, a estabilidade das proteínas pode ser afetada em diferentes taxas de congelamento, dependendo dos mecanismos de desnaturação da proteína (Wang, 2000).

Deve-se notar que a taxa de congelamento pode ter um impacto potencial na estabilidade durante o armazenamento das proteínas liofilizadas. Hsu et al. (1995) demonstraram que o resfriamento mais rápido durante a liofilização do plasminogênio ativador tecidual (tPA) resultou em um produto sólido com uma área de superfície interna maior, conduzindo à formação de mais partículas opalescentes (insolúveis) no armazenamento por um longo período, a $50^{\circ} \mathrm{C}$. A taxa de formação de partículas opalescentes durante $\mathrm{o}$ armazenamento 
correlacionou bem $(r=0,995)$ com a área da superfície interna do produto sólido de tPA liofilizada.

A taxa de congelamento influencia a extensão da cristalização do excipiente da formulação, tal como o manitol. Consequentemente a duração do tratamento térmico subseqüente ao congelamento pode ser afetada. Além disso, diferentes taxas de congelamento podem favorecer a formação de determinadas formas cristalinas de um excipiente, as quais podem afetar potencialmente a estabilidade e reconstituição da proteína. Tem sido observado que uma taxa de cristalização mais lenta tende a favorecer a formação de $\gamma$-glicina, enquanto que a cristalização rápida parece favorecer a formação do $\beta$-polimorfo. Diferentes polimorfos de manitol foram também obtidos em diferentes concentrações durante o congelamento. Recentemente, Kim et al. (1998) demonstraram que o congelamento lento (por volta de $0,2^{\circ} \mathrm{C} \min ^{-1}$ ) de manitol a $10 \%(\mathrm{w} / \mathrm{v}$ ) produziu uma mistura de polimorfos $\alpha$ e $\beta$ e o congelamento rápido (com nitrogênio líquido) da mesma solução produziu a forma $\partial$. O tempo de reconstituição (com água) foi de 36 e 78 s para o congelamento rápido e o congelamento lento, respectivamente, para as amostras de manitol liofilizado.

\subsection{DSC, temperatura de transição vítrea e estabilidade da proteína}

A liofilização é freqüentemente usada para estabilizar os produtos protéicos com baixa estabilidade em solução. Não é surpresa, então, que mais de um quarto dos produtos protéicos terapêuticos no mercado sejam liofilizados. O mecanismo de uma liofilização, congelamento seguido de secagem, induz a obtenção de produtos que em sua maioria estão no estado amorfo. Devido à natureza amorfa da proteína e dos agentes estabilizantes (mais comumente açúcares ou polióis), as formulações liofilizadas exibem freqüentemente uma transição vidro-borracha que é um importante parâmetro para o desenvolvimento do ciclo de liofilização. Então, a transição vítrea de um produto liofilizado pode ser estudada e aplicada para melhorar o processamento, a qualidade e estabilidade do produto (Chen, et al., 1995).

A teoria da transição vítrea origina-se da ciência dos polímeros. As proteínas, sendo poliméricas, podem exibir uma transição vítrea específica $T_{g}$, geralmente ao redor de $-10^{\circ} \mathrm{C}$. Por exemplo, a $T_{g}$ para a ovoalbumina é de $-11^{\circ}$ 
$\mathrm{C},-13^{\circ} \mathrm{C}$ para a lisozima, $-9^{\circ} \mathrm{C}$ para a lactato desidrogenase e $-11^{\circ} \mathrm{C}$ para $\mathrm{o}$ soro da albumina bovina (Chang et al., 1992)

Sob temperaturas abaixo da transição vítrea, a matriz do soluto assemelha-se à um vidro, comportando-se como um sólido amorfo. Em uma liofilização, se a temperatura de congelamento ultrapassar a $T_{g}$, a solução amorfa concentrada ficará menos viscosa, ocorrendo o colapso do produto. Durante a liofilização, a concentração do soluto da matriz aumenta progressivamente devido à perda de água. A matriz torna-se mais rígida e a $T_{g}$ aumenta. $\mathrm{O}$ produto pode então tolerar o aumento da temperatura sem sofrer o colapso (Chen et al., 1995).

A $T_{g}$ é uma transição de segunda ordem e é caracterizada por uma interrupção na relação entre temperatura e capacidade calorífica.

Para definir $T_{g}$ usando DSC, devem ser seguidos três critérios:

- O mapeamento térmico tem de mostrar uma clara descontinuidade do fluxo de calor;

- Deve ser possível mapear antes e depois da transição, de forma reversível entre os estados vítreo e borrachoso;

- Ao manter uma amostra isotermicamente acima de $T_{g}$, a cristalização deve ocorrer (Wolanezyk et. al., 1989).

O terceiro critério é, às vezes, difícil de ser encontrado, porque a cristalização pode levar menos de $10 \mathrm{~min}$ para a lactose e sacarose amorfas (Ross et. al., 1991), $24 \mathrm{~h}$ para o fenobarbital, ou mais de 2 anos para indometacina ( Pikal et. al., 1991). Porém, a sacarose liofilizada cristalizou-se após o armazenamento por apenas um mês a $60^{\circ} \mathrm{C}$ (te Booy, et al., 1992)

A $T_{g}$ também depende da composição da solução protéica. Como previamente mencionado, a $T_{g}$ é independente da concentração para soluções diluídas, mas é dependente da proporção dos componentes. Uma técnica para aumentar a sensibilidade da deteç̧ão é aumentar a concentração de cada componente enquanto se mantém uma relação constante entre as taxas dos componentes. A $T_{g}$ aumenta proporcionalmente com o peso molecular de uma série homóloga de materiais poliméricos. Além disso, um aumento no conteúdo de umidade diminui a $T_{g}$ de um sólido amorfo. Os mesmos pesquisadores relataram que um aumento de $1 \%$ na umidade reduziu a $T_{g}$ em $5^{\circ} \mathrm{C}$ na maioria das amostras. A história térmica de uma amostra é importante e afetará a $T_{g}$ medida. Portanto, é recomendado que as amostras sejam aquecidas a uma alta 
temperatura para apagar qualquer estrutura residual vítrea, que permaneça de algum tratamento térmico prévio. Certamente, a estabilidade da amostra a esta temperatura deve ser levada em consideração. É provável que a possibilidade de haver ainda uma estrutura residual na amostra que será analisada seja a razão pela qual alguns autores sugerem que um segundo mapeamento deva ser usado como a $T_{g}$ representativa do material (Chen, et al., 1995).

Outros fatores importantes que podem influenciar a $T_{g}$ são: a taxa de resfriamento, a taxa de aquecimento, a temperatura e o tempo utilizados durante o tratamento térmico. Estes fenômenos estão bem documentados. O controle adequado dos fatores acima citados evita problemas associados à sobreposição de picos, eliminam a desvitrificação e a micro-heterogeneidade que ocorre durante o resfriamento. Para evitar a sobreposição do pico endotérmico com a transição vítrea, utiliza-se uma rápida taxa de aquecimento, pelo menos $10-40{ }^{\circ} \mathrm{C} \mathrm{min}^{-1}$. $\mathrm{O}$ tratamento térmico, baseado no congelamento da amostra abaixo da $\mathrm{T}_{\mathrm{g}}$ específica do material, seguido do aquecimento da amostra até temperatura de superresfriamento da solução e em seguida, o congelamento do material até temperatura abaixo da $\mathrm{T}_{\mathrm{g}}$, é necessário para algumas amostras para atingir uma concentração máxima de congelamento e eliminar a desvitrificação que é típica das soluções de carboidrato sem tratamento térmico. Sugere-se que o tratamento térmico elimine os diferentes estados polimórficos dos cristais que ocorre durante o resfriamento (Chen et. al., 1995).

O colapso é uma característica de um material que sofreu uma transição vítrea. Ocorre na interface de sublimação, quando o gelo dendrítico é sublimado a uma temperatura acima da temperatura de colapso $\left(T_{c}\right)$. A solução concentrada não tem viscosidade suficiente para suportar sua própria estrutura, sem o suporte adicional do gelo puro que havia sido previamente imobilizado. Quando o gelo puro é sublimado, o líquido viscoso flui para dentro das cavidades da interface e colapsa-se. Em seguida, devido à ebulição, a matriz expandi-se. Isto deixa uma camada que normalmente atua como uma barreira, reduzindo o resfriamento evaporativo. O produto ganha calor sensível, promovendo uma reação em cadeia. O colapso sempre ocorre na mesma temperatura de solidificação do material. Não há efeito de histerese como no caso do congelamento e fusão. Embora o mecanismo de colapso seja diferente do da 
fusão, os agentes causadores e as soluções remediativas são similares (Murgatroyd et. al., 1997)

Valores de $T_{g}$ obtidos por DSC foram relacionados a valores da temperatura de colapso $\left(T_{c}\right)$, medidos por criomicroscopia (Chang et. al., 1992, Ross, 1993). Chang e Randall (1992) observaram uma estreita relação entre a $T_{g}$. e o fenômeno do colapso. Entretanto, Pikal e Shah (1990) sustentaram que a diferença entre $T_{g}$. e $T_{c}$ é sutil mas possivelmente importante. Eles relataram que a $T_{g}$. é ligeiramente menor que a $T_{c}$ quando medida sob baixas taxas de aquecimento. Mais tarde, Pikal concordou que a $T_{g}$. e a $T_{c}$ são idênticas para a maioria dos propósitos práticos ( Pikal, 1990).

Em resumo, a escolha das condições de liofilização é dependente da formulação e o DSC é um método conveniente para avaliar estes efeitos (Chen et. al., 1995).

\subsection{Espectroscopia Raman}

As proteínas e seus componentes são exemplos da aplicação da espectroscopia Raman a biomoléculas. O primeiro espetro Raman de uma proteína, a lisozima, foi obtido em 1958, por Garfinkel e Edsall, utilizando lâmpada de mercúrio como fonte de excitação. $O$ uso intensivo da técnica Raman foi iniciado na década de 70 , com a utilização do laser contínuo a gás e o aperfeiçoamento global da instrumentação.

No Raman temos um processo físico denominado espalhamento de luz. Sua atividade depende da variação do momento de dipolo induzido (pelo campo eletromagnético incidente) com a vibração.

No espalhamento Raman Stokes um fóton de energia $h v_{0}$ interage com uma molécula no estado vibracional fundamental $E_{1}$ levando-a a um estado intermediário $E_{i}$ (não necessariamente um nível energético da molécula) e é espalhado com energia $h\left(v_{0}-v_{v}\right)$, onde $v_{v}$ é a frequência vibracional correspondente à transição $E_{2}-E_{1}=h v_{v}$. Caso o fóton incidente interaja com a molécula no nível vibracional excitado $E_{2}$ o fóton espalhado pode, por decaimento do nível intermediário $E_{i}$ ao estado fundamental $E_{1}$, ter energia $h\left(v_{0}+v_{v}\right)$, maior do que a do fóton incidente, dando origem ao espalhamento Raman anti-Stokes. 
Se o fóton incidente sofre uma colisão puramente elástica será espalhado com a mesma frequência, originando a radiação Rayleigh (Chase et. al., 1994).

A frequência vibracional é obtida da diferença entre a frequência da radiação incidente e a frequência da radiação espalhada. É uma maneira de transpor para a região do visível, informações que seriam obtidas na região do infravermelho.

No efeito Raman não se dá a absorção de energia da radiação incidente. Na realidade usa-se luz visível, de comprimento de onda arbitrário, cuja frequência está distante daquelas das vibrações moleculares.

O que ocorre no efeito Raman é um espalhamento da luz incidente, que após o processo, se apresenta com frequência menor do que a original. A grosso modo poderíamos interpretar o fenômeno como uma colisão inelástica entre um fóton e a molécula (Chase et. al., 1994).

As diferenças de frequências entre a radiação incidente e a espalhada constituem o espectro Raman. Essas diferenças correspondem às frequências de vibração da molécula.

Como o mecanismo do espalhamento Raman é fisicamente diferente daquele de absorção, as regras de seleção para os dois tipos de espectroscopia vibracional molecular são em geral diferentes. Essa diferença é que torna os dois efeitos complementares, pois uma frequência proibida na absorção pode ser emitida no Raman e vice-versa (Chase et. al., 1994).

No efeito Raman não é o momento de dipolo intrínsico da molécula ( $\mu$ ) que está em jogo, mas um momento de dipolo induzido na molécula pelo campo elétrico da radiação incidente $(P)$.

Para campos elétricos não muito intensos existe uma relação linear entre o momento de dipolo induzido e o campo elétrico incidente :

$$
P=\alpha \mathrm{E}
$$

$\alpha$ é a polarizabilidade da molécula. Em geral $P$ e E não são paralelos; consequentemente $\alpha$ não é uma quantidade escalar comum (Chase et. al., 1994).

O espectro Raman normal de uma proteína consiste das contribuições dos modos vibracionais de várias cadeias laterais dos resíduos de aminoácidos 
juntamente com os modos do esqueleto peptídico. Estes modos vibracionais fornecem informações estruturais, como conformação média do esqueleto polipeptídico, a microvizinhança de algumas cadeias laterais (particularmente aquelas da tirosina, do triptofano e da metionina) e a conformação das pontes dissulfetos existentes na proteína (Stuart, 1997).

A espectroscopia por infravermelho tem sido utilizada para quantificar a estrutura secundária da proteína e para estudos das alterações induzidas na conformação da proteína. A informação estrutural é obtida pela análise da faixa na região da amida I conformacionalmente sensível que situa-se entre 1.600 e 1.700 $\mathrm{cm}-1$. Esta banda é sensível ao estiramento vibracional das ligações $\mathrm{C}=\mathrm{O}$, fracamente ligadas ao estiramento $\mathrm{C}-\mathrm{N}$ e N-H. Cada tipo de estrutura secundária ( $\alpha$-hélice, folhas- $\beta$ e estruturas desordenadas) causam 0 aumento de uma freqüência de estiramento de $\mathrm{C}=\mathrm{O}$ diferente e, portanto, apresentam uma posição de faixa característica, a qual é designada pelo número da onda $\mathrm{em}^{-1}$. As posições das faixas são usadas para determinar os tipos estruturais secundários presentes em uma proteína. As áreas de faixa relativa podem então ser utilizadas para quantificar cada componente estrutural. Conseqüentemente, uma análise das faixas por espectroscopia infravermelho na região da amida I pode fornecer informação tanto quantitativa como qualitativa sobre a estrutura secundária da proteína.

Para obter essa informação estrutural detalhada, é necessário aumentar a resolução da faixa de amida I da proteína, que geralmente aparece como um único amplo contorno de absorbância.

Para os estudos de alterações estruturais induzidas pela liofilização recomenda-se o cálculo do segundo espectro derivativo. Este método é muito objetivo e as alterações nas larguras das faixas componentes, as quais são devidas ao desdobramento da proteína são preservadas no segundo espectro derivativo (Carpenter et al., 1999).

Para a maioria das proteínas não protegidas, (liofilizadas na presença apenas de tampão), o segundo espectro derivativo para o sólido seco é bastante alterado, correspondendo ao respectivo espectro das proteínas originais em soluções aquosas. A liofilização induz a diferentes níveis de deslocamento nas posições de faixas, perda e alargamento de faixas. 
As alterações espectrais induzidas pela liofilização na região conformacionalmente sensível da amida I ocorrem devido o desdobramento da proteína e não simplesmente à perda de água pela mesma. Os efeitos intrínsecos da remoção da água nas propriedades de oscilação da ligação de peptídeo e, por conseguinte, no espectro infravermelho da proteína, foram tidos como insignificantes por Prestrelski e outros. Se os efeitos diretos de oscilação da remoção da água foram responsáveis pelas alterações espectrais induzidas pela secagem, então o espectro infravermelho de todas as proteínas deveria ser alterado para o mesmo grau no sólido seco, o que não é o caso (Carpenter et. al., 1999).

A liofilização pode causar diversas mudanças potenciais no espectro IR das proteínas. A perda das ligações de hidrogênio nas proteínas durante a liofilização geralmente leva a um aumento na freqüência e uma diminuição na intensidade das faixas de expansão da hidroxila. O desdobramento das proteínas durante a liofilização amplia e modifica (para números de ondas maiores) os picos dos componentes da amida I. A liofilização freqüentemente conduz a um aumento no conteúdo de folhas- $\beta$ com uma redução concomitante no conteúdo de $\alpha$-hélice. A conversão da $\alpha$-hélice para folhas- $\beta$ durante a liofilização tem sido observada em muitas proteínas, tais como o toxóide tetânico (TT) 10mM de tampão de fosfato de sódio ( $\mathrm{pH} 7,3$ ), albumina humana recombinante ( $\mathrm{AHr}$ ) em soluções com diferentes tampões e em diferentes pHs, Hormônio do crescimento humano (GHh) em $\mathrm{pH}$ 7,8 e sete proteínas modelos em solução, incluindo o inibidor tripsina pancreática bovina (ITPB), a quimiotripsinogênio, a mioglobina do cavalo (Mb), o citocromo c cardíaco eqüino (Cytc), a AHr, a insulina suína e a Ribonuclease $A$ (RNase A) (Griebenow et al., 1995).

Um aumento no conteúdo de folhas- $\beta$ durante a liofilização é freqüentemente uma indicação de agregação protéica e/ou aumento da interação intermolecular. Tal transição tem sido também observada nas proteínas durante a liofilização, assim como a insulina humana em solução $(\mathrm{pH} 7,1)$. As estruturas de folhas- $\beta$ após a liofilização apresenta um grau maior de ligação intermolecular de hidrogênio porque os grupos polares precisam satisfazer suas necessidades de ligação H - H pela interação intra ou intermolecular pela remoção da água. A folha$\beta$ intermolecular é caracterizada por duas principais faixas de IR de aproximadamente 1617 e $1697 \mathrm{~cm}^{-1}$ no estado sólido, que pode ser usadas para 
monitorar a desnaturação da proteína. Similarmente, a intensidade relativa da faixa a-hélice pode ser usada nesta observação (Heller et al., 1999).

Como a maioria das proteínas terapêuticas são administradas parenteralmente, mesmo se apenas uma pequena fração do total da quantidade das moléculas de uma proteína (uma pequena porcentagem) estiver irreversivelmente desnaturada e agregada, então o produto não será aceitável. Até recentemente, eram desconhecidas as alterações na estrutura da proteína surgidas durante a liofilização, os quais eram usualmente manifestadas como agregação protéica após a reidratação. Entretanto, com a espectroscopia por infravermelho, agora é possível examinar-se diretamente a estrutura secundária de uma proteína na solução aquosa inicial, tanto no estado líquido como no sólido final desidratado. O desdobramento não só pode levar à desnaturação irreversível da proteína, se a amostra é reidratada imediatamente, mas talvez com maior importância para o desenvolvimento industrial de proteínas liofilizadas, pode também reduzir a estabilidade durante $\mathrm{o}$ armazenamento no sólido seco (Carpenter et al., 1998).

Além do mais, a simples obtenção de uma proteína nativa em amostras reidratadas imediatamente após a liofilização não é necessariamente indicativo de adequada estabilização durante as etapas de processamento, nem de previsão de estabilidade de armazenamento. Por exemplo, muitas proteínas são desdobradas durante a liofilização, mas são prontamente restauradas se reidratadas imediatamente.

A informação estrutural é obtida pela análise da faixa de amida I conformacionalmente sensível, a qual está localizada entre 1.600 e $1.700 \mathrm{~cm}^{-1}$. As alterações espectrais na região sensível da amida I induzidas pela liofilização são devido ao desdobramento da proteína e não simplesmente à perda de água do sistema. Os efeitos intrínsecos da remoção de água nas propriedades vibracionais da ligação peptídica e, conseqüentemente, os espectros infravermelhos da proteína, foram tidos como insignificante por Prestrelski e colaboradores (Carpenter et. al., 1998).

São mostrados dois comportamentos diferentes das proteínas desdobradas no sólido seco durante a reidratação :

- a proteína recupera a conformação original pela reidratação (desdobramento reversível), como observado para a-lactoalbumina, lisozima, 
quimiotripsinogênio, ribonuclease, $\beta$-lactoglobulinas $A$ e $B$, $\alpha$-quimiotripsina e subtilisina ;

- uma fração significativa das moléculas de proteína agregam-se com a reidratação (desdobramento irreversível), como notado para a Lactato desidrogenase (LDH), Fosfofrutoquinase (PFK), Interferon-y, fator de crescimento de fibroblasto básico e interleucina-2 ( Prestrelski et al., 1993)

Tem sido documentado com várias proteínas, que a prevenção da agregação e o restabelecimento da atividade após a reidratação correlaciona-se diretamente com a retenção da estrutura original no sólido seco (Carpenter et. al., 1999). .

A extensão das alterações em todo o espectro IR de uma proteína pela liofilização reflete o grau de desnaturação da proteína. As mudanças relativas a uma referência do espectro podem ser medidas usando-se um coeficiente de correlação (r), como definido por Prestrelski et al., (1993), ou a extensão da cobertura da área do espectro. Utilizando o coeficiente de correlação, Prestrelski et al. (1993) foram capazes de medir a estabilidade da liofilização de diversas proteínas modelo, incluindo o fator de crescimento do fibroblasto básico (bFGF), a a-lactoalbumina bovina, a a-caseína bovina, o Interferon- $y$, e o fator estimulante da colônia recombinante de granulócito (rG-CSF) na presença de diferentes açúcares. Todavia, Griebenow e Klibanov (1995), após analisarem as estruturas secundárias de sete proteínas modelo na liofilização, concluíram que o coeficiente de correlação não era altamente sensível às alterações estruturais nas proteínas.

\subsection{Umidade residual}

O conteúdo de umidade residual após a liofilização freqüentemente controla a estabilidade da proteína por um longo período, tanto física como quimicamente. O conteúdo de umidade de uma fórmula de proteína liofilizada pode mudar significativamente durante o armazenamento, devido a uma variedade de fatores, tais como: liberação de umidade pela rolha butílica e entrada de ar para o interior do frasco contendo o produto liofilizado, cristalização de um excipiente amorfo, ou liberação de umidade de um excipiente hidratado. A água pode afetar a estabilidade da proteína tanto indiretamente (agindo como um 
plasticizante, ou como meio de reação), como diretamente (como um reagente ou um produto de reação) (Wang, 2000).

O método de titulação por Karl Fischer, originalmente descrito em 1935, é a abordagem mais utilizada na determinação do conteúdo de água residual. O método Karl Fischer fornece uma melhor estimativa da umidade residual total, é bastante reprodutível e pode ser automatizado. A titulação pode ser feita em meio prótico ou aprótico, porém quando realizada em meio prótico, a análise torna-se mais ampla devido à maior sensibilidade do agente titulante da amostra e composição do solvente (Towns, 1995).

A habilidade do método de Karl Fischer de medir a umidade residual em aproximadamente $10 \mathrm{mg}$ de uma amostra biológica liofilizada faz dele o método mais prático para a determinação da umidade residual em produtos biológicos liofilizados em uma dose única. Os produtos liofilizados não podem ser analisados pela metodologia de Karl Fischer quando:

- Os materiais presentes na matriz do produto interferem nos reagentes de Karl Fischer;

- A amostra não se dissolve adequadamente no reagente de Karl Fischer;

- A umidade da amostra não extrai adequadamente nestes solventes (Towns, 1995).

Um importante ponto a ser considerado na titulação de Karl Fischer é a possibilidade de resultados falsos devido à contaminação da água durante o manuseio da amostra. Indiretamente como um plasticizante, a água diminui drasticamente a temperatura de transição vítrea das proteínas, polímeros ou excipientes da formulação. O efeito quantitativo da água na temperatura de transição vítrea pode ser facilmente estimado pela equação de Gordon-Taylor. A queda da $T_{g}$ pela água pode atingir $10^{\circ}$ ou mais para cada percentagem de umidade retida, especialmente em conteúdos com baixo nível de umidade. Além disso, uma proteína liofilizada pode absorver facilmente quantidades suficientes de umidade durante o armazenamento para reduzir sua $T_{g}$ abaixo da temperatura de armazenamento, acelerar sua instabilidade e causar um possível colapso do produto. Por exemplo, a dimerização da insulina liofilizada aumenta significativamente quando o conteúdo de água é alto o suficiente para causar a diminuição significativa da temperatura de transição vítrea e o colapso do sólido. $O$ 
alto conteúdo de umidade também facilita a cristalização dos excipientes da fórmula, tais como os açúcares (Wang, 2000).

Geralmente, o aumento do conteúdo de umidade de uma proteína liofilizada aumenta a taxa de degradação das proteínas. A água absorvida aumenta o volume livre de uma proteína liofilizada, promovendo a mobilidade molecular.

A perda da atividade da RNase pancreática bovina induzida pela aglutinação foi mais rápida a $9,8 \%$ de umidade do que a 1,9\%. O aumento da umidade foi também a causa da conformação $\alpha$-helicoidal reduzida e a estrutura $\beta$ aumentada (um tema comum da aglutinação da proteína) do fator estimulante de colônias de granulócitos humano recombinante (rhG-CSF) desidratado por spraydrying (French et al., 1995).

O processo de liofilização remove a água de um sistema, baseado no princípio da sublimação do gelo sob pressão reduzida. Quando uma solução protéica é liofilizada, o volume de água que reside nas matrizes de gelo da solução congelada sublima primeiro. As multicamadas da água que envolvem a molécula de proteína é então removida, deixando uma monocamada residual de água na superfície da proteína. Esta operação permite a secagem dos materiais termolábeis para diminuir o conteúdo de umidade residual sob moderadas condições de temperatura. Se o produto cujo fim é o uso parenteral, então a proteína é geralmente liofilizada em um recipiente final tal como a ampola de vidro lacrada ou um recipiente de vidro com fecho de borracha, que é usualmente fechado a vácuo ou nitrogênio. O conteúdo de água do material liofilizado no recipiente final pode variar dependendo dos parâmetros da liofilização e pode aumentar durante o armazenamento (Towns, 1995).

A quantidade de água presente na proteína tem um significativo impacto na estabilidade e é uma preocupação tanto para o volume do sólido como para as formulações liofilizadas. A umidade residual refere-se ao baixo nível da água da superfície, variando desde menos de $1 \%$ até $5 \%$, permanecendo em um produto biológico liofilizado após a remoção do volume do solvente. A umidade residual não deveria comprometer a potência e integridade do produto. O nível apropriado de umidade residual para otimizar a estabilidade de uma proteína liofilizada é muito dependente dos caminhos específicos para a decomposição da mesma. A visão geralmente aceita é quanto mais seco melhor. Porém, os níveis 
de umidade residual de certos produtos não deveriam ser tão baixos a ponto do excesso de secagem afetar adversamente a estabilidade do produto. A retenção de água varia de acordo com o tipo de água presente, tipo de ligação, superfície e/ou água retida, e é diferente para cada produto. Como pode existir mais de um tipo de água em um produto biológico liofilizado, podem ser encontrados diferentes resultados de umidade quando são empregados diferentes métodos na determinação do conteúdo de umidade da amostra (Towns, 1995).

\section{OBJETIVO}

O objetivo do presente trabalho foi:

- Analisar a influência da taxa de congelamento no comportamento físicoquímico e estrutural durante a liofilização da albumina bovina;

- Avaliar o efeito da liofilização sobre a estrutura e mudanças de fase da albumina bovina modificada por reação com o metoxi-polietilenoglicol.

\section{MATERIAIS E MÉTODOS}

\subsection{Materiais.}

Albumina bovina fração $\mathrm{V}$ (fracionamento por metodologia Cohn) pó cristalizado da marca INLAB.

Metoxipolietilenoglicol (P.M. $5000 \mathrm{Da}$ ), pó cristalizado da marca Aldrich.

\subsection{Métodos}

\subsubsection{Solução de $B S A$}

Preparou-se uma solução de albumina bovina (100 mg/ml) em tampão Fosfato $(\mathrm{pH} 7,3) 0,1 \mathrm{M}$ em temperatura controlada de aproximadamente $2{ }^{\circ} \mathrm{C}$. 


\subsubsection{Determinação da temperatura de transição vítrea}

A temperatura de transição vítrea da solução e do pó liofilizado da albumina bovina foi determinada utilizando-se DSC 822 da METTLER TOLEDO, com taxa de resfriamento de $5^{\circ} \mathrm{C} / \mathrm{min}$, taxa de $\mathrm{N}_{\mathrm{z}}$ de $50 \mathrm{ml} / \mathrm{min}$.

\subsubsection{Análise estrutural}

A estrutura secundária da albumina bovina (solução e pó liofilizado) foi determinada por espectroscopia RAMAN da marca BRUKER, IFS 28/N com acessório FRA 106/S. Utilizou-se resolução espectral de $4 \mathrm{~cm}^{-1}$ e $128 \mathrm{n}^{\text {os }}$ de aquisições.

\subsubsection{Determinação do teor de umidade residual}

A umidade residual do pó liofilizado da albumina bovina foi determinada por metodologia Karl Fisher em equipamento da METTLER TOLEDO DL 31 KARL FISHER TITRATOR.

\subsubsection{Liofilização da albumina bovina nativa}

A liofilização foi conduzida em um liofilizador da marca FTS Systems, modelo TDS-00209-A e micro processado pelo programa Liphoware.

$\mathrm{O}$ congelamento com taxa de resfriamento de $2,5^{\circ} \mathrm{C} / \mathrm{min}$ foi realizado em um Ultrafreezer com temperatura final de $-70^{\circ} \mathrm{C}$. O congelamento com taxa de resfriamento de $30^{\circ} \mathrm{C} / \mathrm{min}$ foi realizado com a imersão das amostras em Nitrogênio líquido.

A secagem primária foi realizada com temperatura de placa de $-22^{\circ} \mathrm{C}$, pressão interna na câmara de 250 mTorr e temperatura do condensador de $90^{\circ} \mathrm{C}$. A secagem secundária foi realizada com temperatura de placa de $25^{\circ} \mathrm{C}$, pressão interna na câmara de $5 \mathrm{mTorr}$ e temperatura do condensador de $-90^{\circ} \mathrm{C}$.O final da liofilização foi determinado por um higrômetro acoplado ao liofilizador. Os 
frascos foram fechados por rolhas butílicas ainda dentro da câmara sob pressão reduzida de 5 mTorr.

\subsubsection{Síntese do metoxi-poietilenoglicol 5000}

Esquema reacional :

Para a obtenção do succinimidil derivado foi necessário fazer a seguinte reação:<smiles>COCCOCCOCCOCCOCCOCCOC(=O)CCC(=O)O</smiles>

PEG $5000 \quad$ anidrido succínico succinimidil derivado

Para obtenção do complexo ativado do metoxi-PEG realizou-se a reação abaixo :
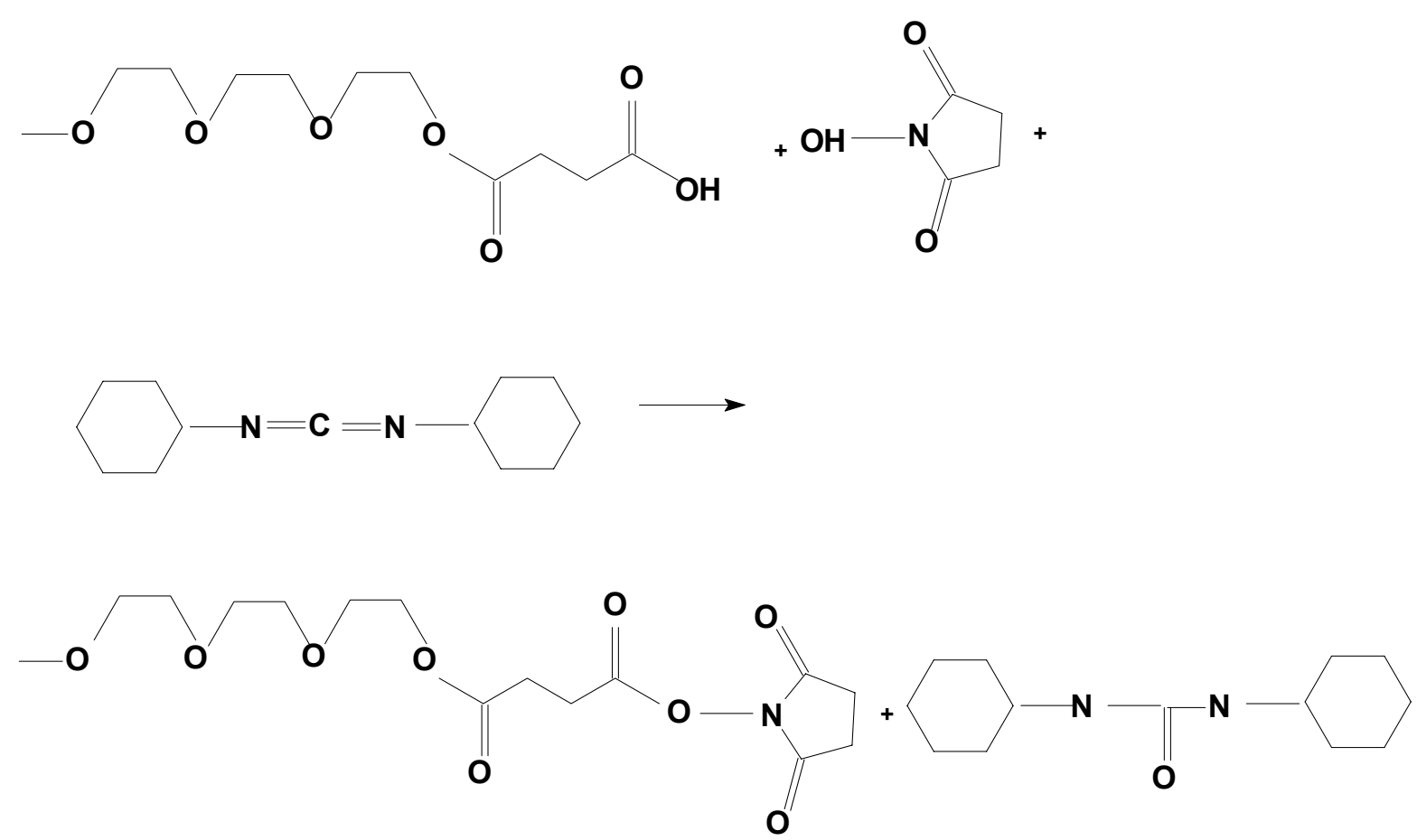

Complexo Ativado

$\mathrm{PM}=5000$ 
As quantidades empregadas na reação de ativação do metoxipolietilenoglicol estão descritas na tabela 2 :

Table 1. Amount spent in the methoxy-polyethyleneglycol activation reaction.

\begin{tabular}{|ll|}
\hline Methoxy PEG 5000 & $15 \mathrm{~g}$ \\
Ethyl Acetate & $150 \mathrm{ml}$ \\
NHS n-hydroxysuccinimide & $0.86 \mathrm{~g}$ \\
DCC diciclohexylcarbodiimide & $1.55 \mathrm{~g}$ \\
\hline
\end{tabular}

Dentro de um reator de vidro com agitação magnética e aquecimento controlado, foram colocados o acetado de etila devidamente desidratado (tal procedimento é dispensável usando-se acetato de etila grau analítico) e o metoxi PEG já na forma de succinimidil derivado. A mistura foi aquecida ligeiramente até a completa dissolução dos reagentes. Após a conservação a $30^{\circ} \mathrm{C}$ por 24 horas, adicionou-se NHS seguido do DCC. Ao termino das 24 horas a massa reacional foi filtrada e em seguida foi posta para resfriar por 24 horas a $5^{\circ} \mathrm{C}$, quando então foi filtrada para isolar o produto sólido que foi lavado com acetado de etila gelado e em seguida posto para secar a vácuo até peso constante. Em seguida o material foi dissolvido em 3 vezes a sua massa em benzeno, e em seguida adicionado do mesmo volume de éter de petróleo, em seguida foi resfriado e filtrado e tal operação foi repetida por mais duas vezes. O rendimento final em metoxi PEG succinimida obtido da maneira descrita acima foi de $74,73 \mathrm{~g}$ de base seca.

Este material foi guardado em frascos com nitrogênio e utilizado na reação de PEGuilação com a albumina bovina.

\subsubsection{Preparação da solução de albumina bovina modificada com metoxi-PEG}

Foram adicionados em 3 recipientes: $150 \mathrm{ml}$ de tampão Fosfato alcalino + $100 \mathrm{ml}$ de solução de albumina bovina $40 \mathrm{mg} / \mathrm{ml}$ tampão fosfato $0,1 \mathrm{M}$.

Em cada recipiente adicionou-se respectivamente 1,0 g (BSA-PEG 1:0,25), 2,0 g (BSA-PEG 1:0,5) e 4,0 g (BSA-PEG 1:1) de PEG 5000 ativado. 
As soluções foram mantidas a $30{ }^{\circ} \mathrm{C}$ e depois foram transferidas para uma câmara resfriada a $8{ }^{\circ} \mathrm{C}$, aonde as soluções permaneceram em repouso até o dia seguinte.

As três amostras foram purificadas em uma coluna de purificação da marca Sephadex G150 calibrada com tampão Tris 100mM, pH 8,6 e eluídas com o mesmo tampão. Após este procedimento a solução de albumina bovina modificada com PEG 5000 foi fracionada em frascos com volume de enchimento de $2,0 \mathrm{ml}$ e liofilizadas.

\subsubsection{Liofilização da albumina bovina modificada com metoxi-polietilenoglicol}

A liofilização foi conduzida em um liofilizador da marca FTS Systems, modelo TDS-00209-A, micro processado pelo programa Liphoware.

O congelamento com taxa de resfriamento de $2,5^{\circ} \mathrm{C} / \mathrm{min}$ foi realizado em um Ultrafreezer com temperatura final de $-70^{\circ} \mathrm{C}$.

A secagem primária foi realizada com temperatura de placa de $-16^{\circ} \mathrm{C} \mathrm{e}$ pressão interna na câmara de 140 mTorr e temperatura do condensador de $90^{\circ} \mathrm{C}$. O tempo de secagem primária foi de 20 horas. A secagem secundária foi realizada com temperatura de placa de $25^{\circ} \mathrm{C}$, pressão interna da câmara de 5 mTorr e temperatura do condensador de $-90^{\circ} \mathrm{C}$. O tempo de secagem secundária foi de 5 horas. $O$ final da liofilização foi determinado por um higrômetro acoplado ao liofilizador. Os frascos foram fechados por rolhas butílicas ainda dentro da câmara sob pressão reduzida de 5 mTorr.

\subsubsection{Análise colorimétrica}

A transmitância da solução de albumina bovina modificada com metoxipoletilenoglicol foi medida através de um colorímetro da marca Color Quest XE da Hunterlab, com raio duplo de xenônio e comprimento de onda de 400 a 700 nanômetros. 


\section{RESULTADOS E DISCUSSÃO}

A figura 2 mostra a curva de DSC referente a amostra de albumina bovina $(100 \mathrm{mg} / \mathrm{ml})$ em tampão fosfato $(\mathrm{pH}=7,3)$ durante a análise térmica da solução congelada.

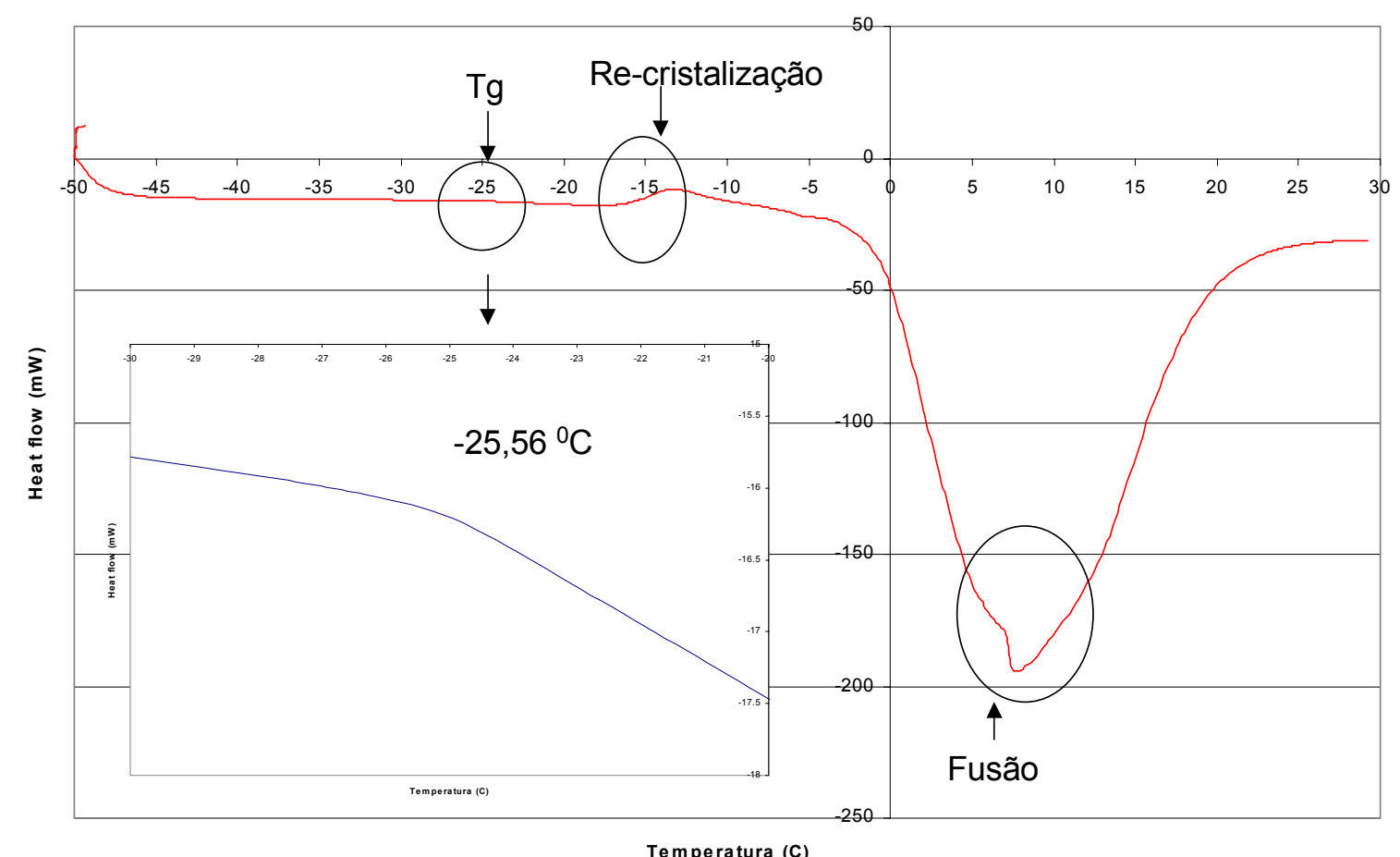

Fig 2. Comportamento térmico da solução de albumina bovina (100 mg/ml) Tampão Fosfato $(\mathrm{pH} 7,3$ / 0,1 M).

Analisando-se a curva, observou-se um declive referente a uma transição de segunda ordem na faixa de $-25{ }^{\circ} \mathrm{C}$ correspondente a temperatura de transição vítrea $(\mathrm{Tg})$. Alguns autores consideram o valor de $\mathrm{Tg}$ como sendo o ponto médio na curva medida pelas extensões da linha de base antes e depois da transição.

Após a Tg, observou-se um pico exotérmico na faixa dos $-15^{\circ} \mathrm{C}$ possivelmente referente à cristalização dos sais do tampão. À temperatura de $8^{\circ} \mathrm{C}$ é observou-se um pico endotérmico atribuído à temperatura de fusão da composição. 
Em uma liofilização, durante a secagem primária, quando o gelo é sublimado, o produto deve ser mantido abaixo da temperatura de colapso que, normalmente, coincide com a transição termotrópica que foi referente à temperatura de transição vítrea da amostra $\left(T_{g}\right)$ ou como a temperatura de relaxamento da fase amorfa (Ts). Além disso, é necessário manter a temperatura da solução abaixo da temperatura de fusão eutética de qualquer componente cristalino. Portanto, estas temperaturas foram determinadas utilizando-se o mapeamento diferencial por varredura (DSC). A secagem de um produto abaixo da temperatura de colapso tem um custo. Quanto mais baixa a temperatura da amostra, mais lento e mais caro o ciclo de liofilização se torna. Em geral, a liofilização de um produto abaixo de $-40^{\circ} \mathrm{C}$ não é viável. Além disso, há limites físicos nas temperaturas nas quais as amostras podem ser reduzidas, limites esses que dependem do liofilizador e das características da amostra (Carpenter et. al., 1997).

Analisando a figura 3, referente à curva de liofilização da albumina em relação às diferentes taxas de congelamento empregadas, podemos observar uma diferença de sete horas na secagem primária, que esta diretamente relacionada com o tamanho, forma e a distribuição dos cristais de gelo formados durante o congelamento.

A liofilização foi conduzida até secagem completa de ambas as amostras, tendo como base, o controle de umidade residual do próprio equipamento. As amostras foram congeladas com duas diferentes taxas de congelamento. Foram liofilizadas sob as mesmas condições: temperatura de placa e pressão, onde, a diferença entre a temperatura de placa e a temperatura de colapso do material, ( $\mathrm{Tp}-\mathrm{Tc}$ ), foram constantes para ambas as amostras. A taxa de congelamento de $2,5^{\circ} \mathrm{C}$ (Ultrafreezer) induziu a formação de cristais de gelo relativamente maiores do que os cristais de gelo formados durante o congelamento utilizando-se $\mathrm{N}_{2}\left(30^{\circ} \mathrm{C} / \mathrm{min}\right)$. Por esta razão observou-se uma diferença de sete horas e meia na secagem primária das amostras. 


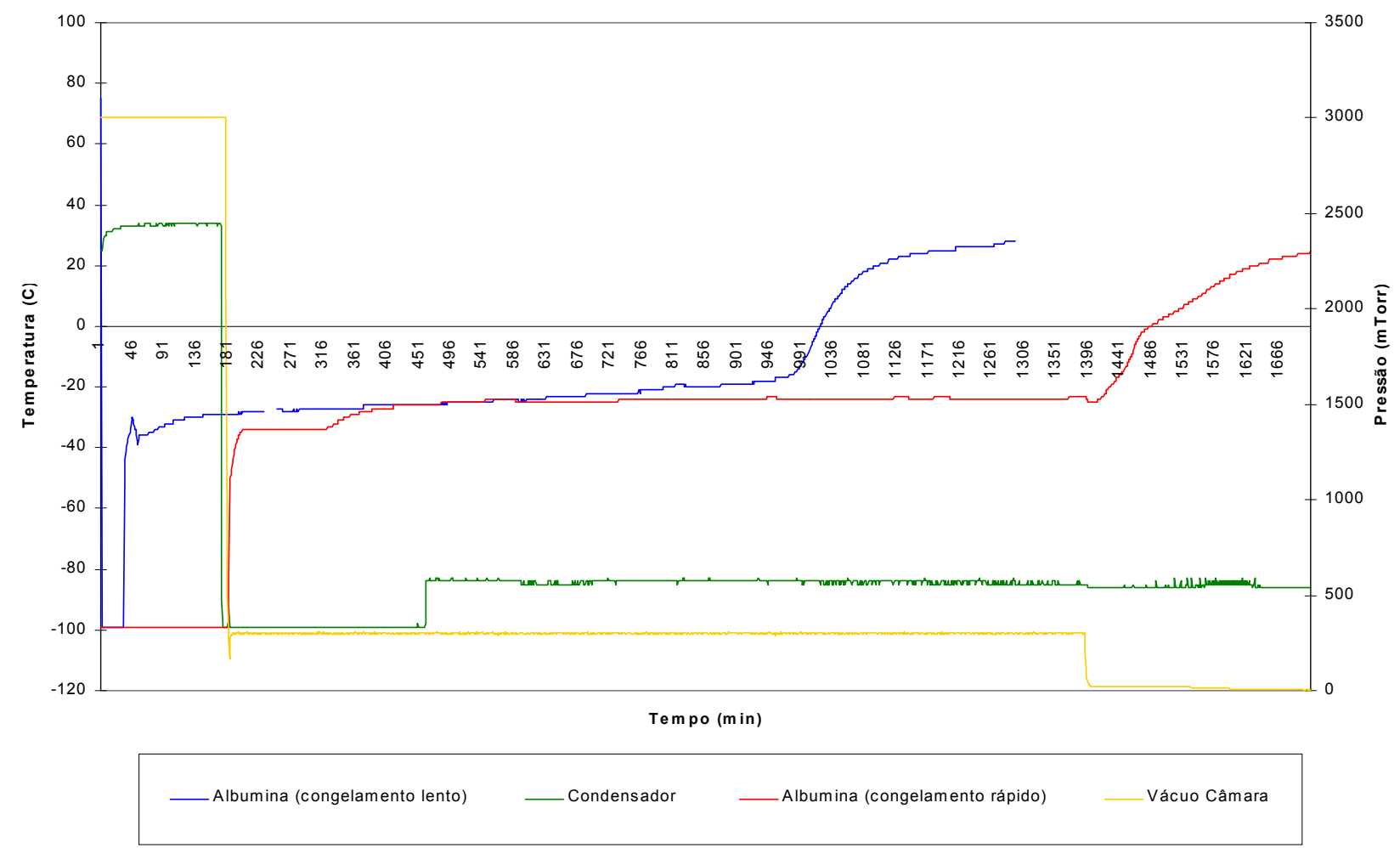

Fig.3. Curvas de liofilização da albumina bovina (100 mg/mL) Tampão Fosfato $(\mathrm{pH} 7.3 / 0,1 \mathrm{M})$ utilizando-se taxa de congelamento de $2,5^{\circ} \mathrm{C} / \mathrm{min}$ (azul) e taxa de congelamento rápido (vermelho).

Os cristais de gelo, formados durante o congelamento da amostra, quando sublimados durante a secagem primária deixam espaços intersticiais, que facilitam e aceleram a sublimação na interface de gelo da solução.

Além disso, para assegurar a estabilidade da proteína liofilizada por um longo período, a temperatura de transição vítrea $\left(T_{g}\right)$ da fase amorfa no produto, o qual contém a proteína, não deve exceder a temperatura de armazenamento planejada. Desde que a água é um plasticizante da fase amorfa, é preciso baixa umidade residual para assegurar que a $T_{g}$ do produto liofilizado seja menor do que a temperatura mais alta encontrada durante o transporte e o armazenamento (geralmente maior que $40^{\circ} \mathrm{C}$ ) (Carpenter et. al., 1997).

Após á liofilização, a albumina bovina pó liofilizado foi submetida à análise térmica por DSC.

$\mathrm{Na}$ figura 4 constatou-se um declive na linha de base horizontal na faixa de $48{ }^{\circ} \mathrm{C}$ durante o aquecimento da albumina bovina pó liofilizado com taxa de 
congelamento de $2,5^{\circ} \mathrm{C} / \mathrm{min}$ e de $37^{\circ} \mathrm{C}$ para a albumina bovina pó liofilizado com taxa de congelamento de $30^{\circ} \mathrm{C} / \mathrm{min}$. (figura 5 ).

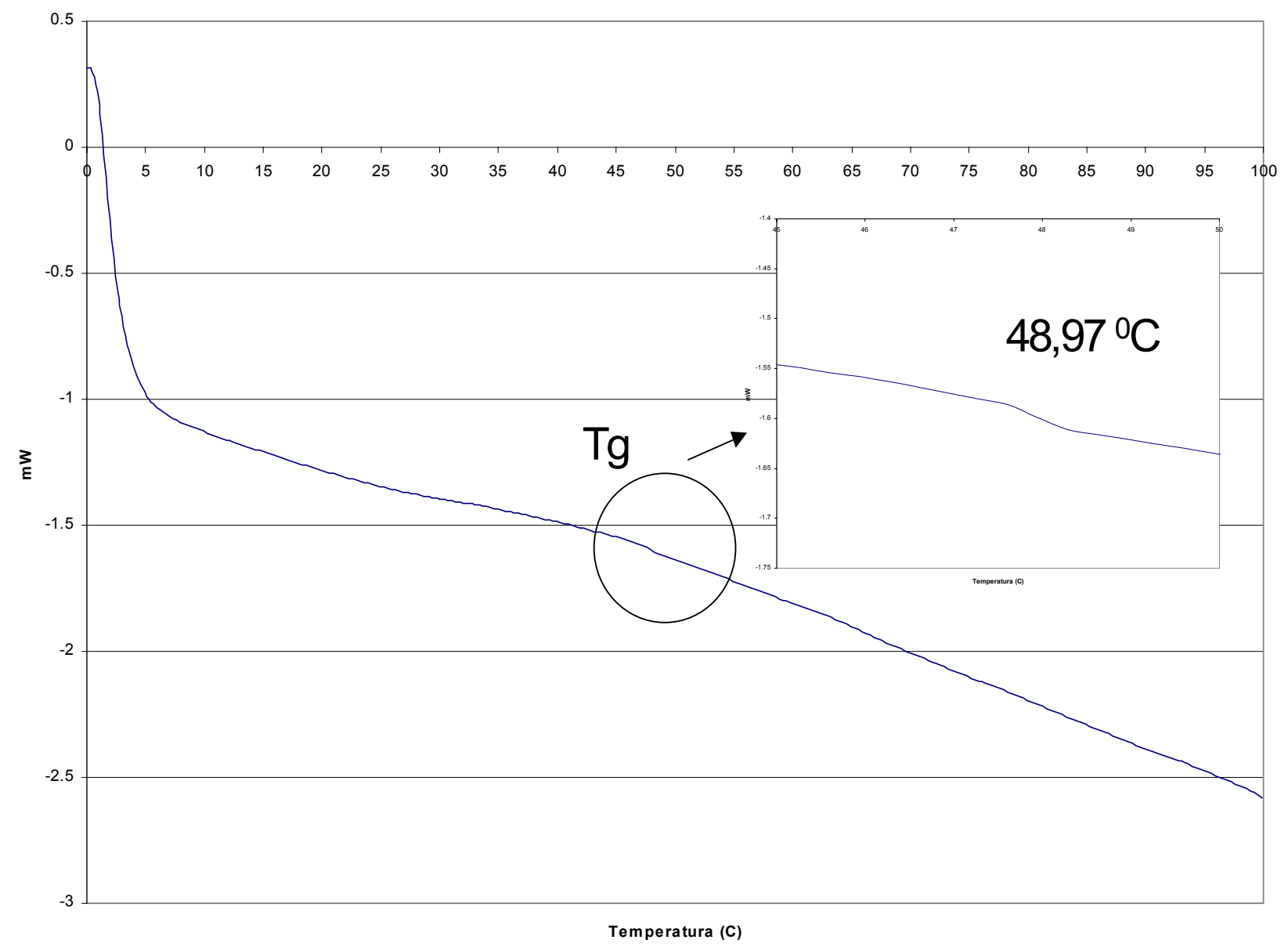

Fig 4. Transição vítrea do pó liofilizado da albumina bovina $(100 \mathrm{mg} / \mathrm{ml})$ Tampão Fosfato (pH 7,3 / $0,1 \mathrm{M})$, taxa de congelamento $\left(2,5^{\circ} \mathrm{C} / \mathrm{min}\right.$.), umidade residual : $4,6 \%$. 


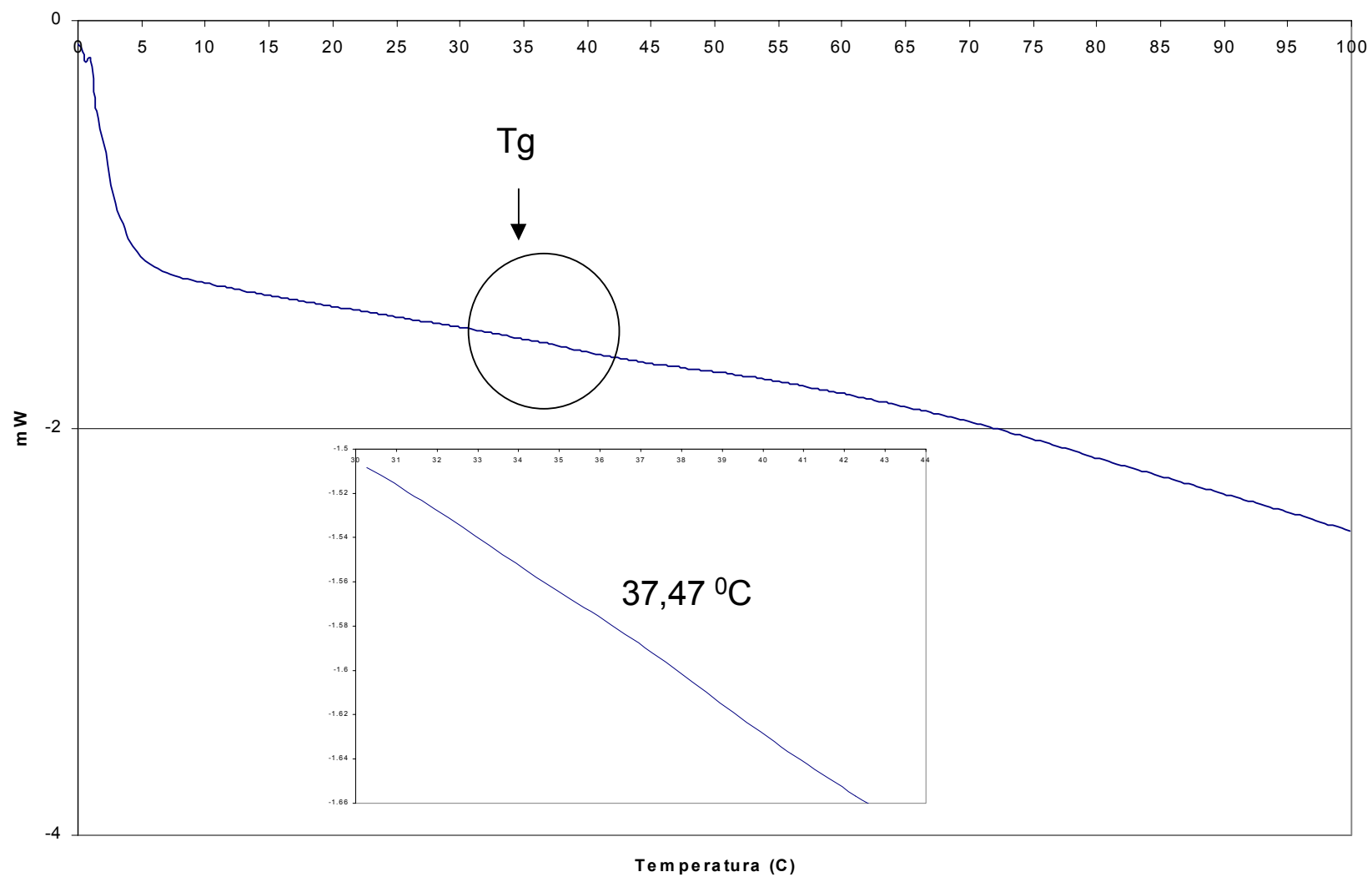

Fig 5. Transição vítrea do pó liofilizado da albumina bovina (100 mg/ml) Tampão Fosfato (pH 7,3 / 0,1 M), taxa de congelamento ( $30^{\circ} \mathrm{C} / \mathrm{min}$.), umidade residual : $11 \%$.

Estes decaimentos nas linhas horizontais de base referem-se à $\mathrm{Tg}$ do pó liofilizado com umidade residual média de 4,6\% e $11 \%$ respectivamente.

Os valores de $\mathrm{pH}$ da albumina reidratada após a liofilização não apresentaram diferenças significantes (desvio padrão: 0,004).

A média dos valores de $\mathrm{pH}$ das amostras de albumina bovina liofilizada com taxa de congelamento de $2,5{ }^{\circ} \mathrm{C} / \mathrm{min}$ foi de 7,2 e para as amostras de albumina bovina liofilizada com taxa de congelamento de $30{ }^{\circ} \mathrm{C} / \mathrm{min}$. foi de 7,1 .

A albumina bovina foi liofilizada nas mesmas condições de secagem (temperatura e pressão), porém variando-se a taxa de congelamento. Observouse que o tempo de secagem primária foi maior para a albumina liofilizada com taxa de congelamento de $30{ }^{\circ} \mathrm{C} / \mathrm{min}$. resultando em um maior valor de umidade residual $(11 \%)$, o que permite supor que o congelamento lento, com umidade residual de $4,6 \%$ pode ter causado danos estruturais liberando a água estrutural que foi removida durante a liofilização. 
O congelamento utilizando-se a taxa de $30^{\circ} \mathrm{C} / \mathrm{min}$ induziu a formação de pequenos cristais de gelo, os quais dificultam a saída do vapor de água durante a secagem primária.

Devido à este fator, supõe-se que a umidade residual da albumina bovina liofilizada utilizando-se taxa de congelamento de $30^{\circ} \mathrm{C} / \mathrm{min}$ foi significantemente maior em virtude do tipo de congelamento empregado.

A figura 6 representa a determinação das regiões da Amida I, II e III por espectroscopia Raman da solução de albumina bovina Tampão Fosfato ( $\mathrm{pH}$ 7,3, 0,1 M) largamente usadas para caracterizar a estrutura secundária da cadeia polipeptídica de uma proteína.

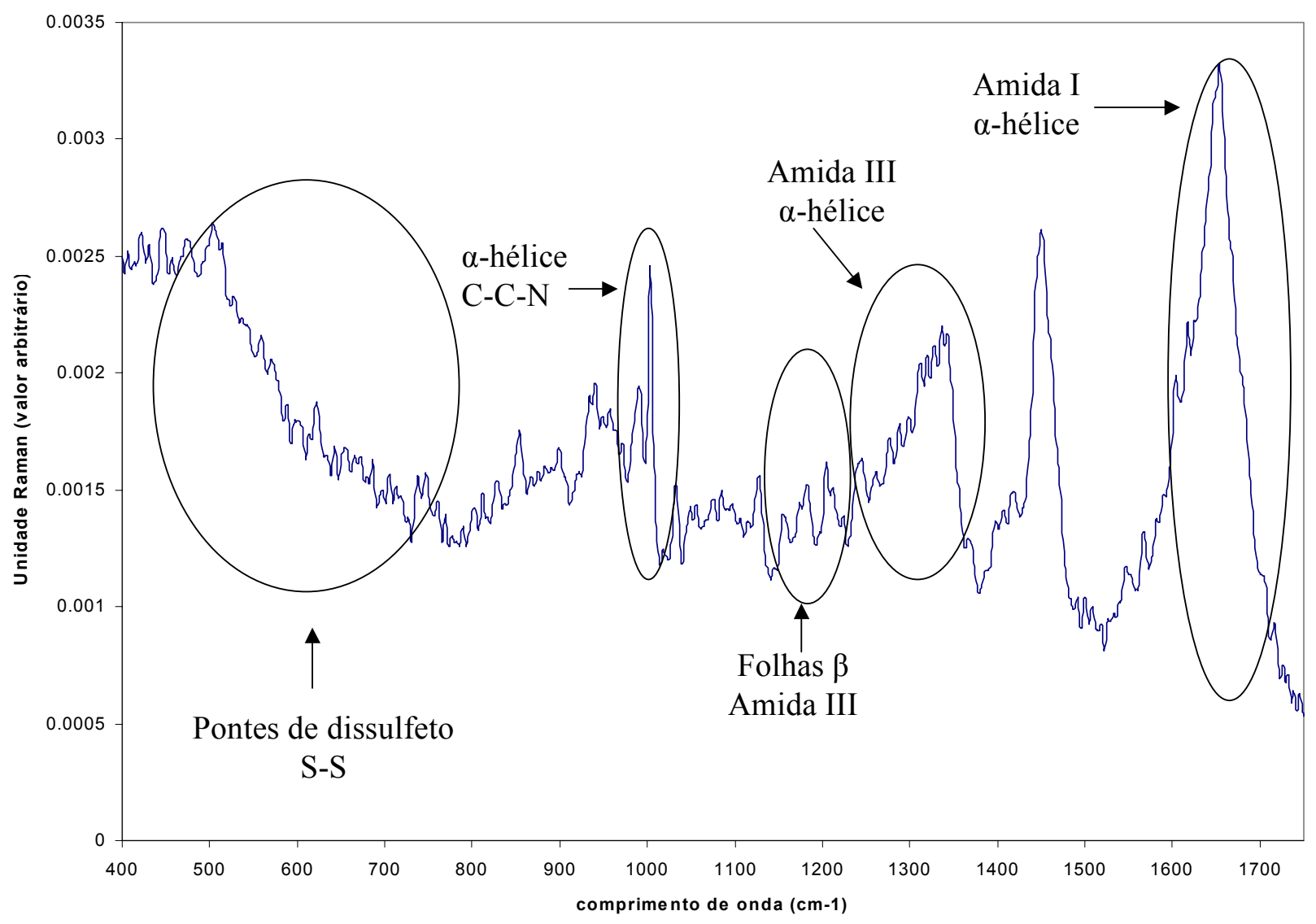

Fig.6. Espectro Raman das regiões da Amida I, II e III da solução de albumina bovina (100 $\mathrm{mg} / \mathrm{mL})$ Tampão Fosfato (pH 7.3) (0,1 M).

A amida I é caracterizada pelo estiramento $\mathrm{C}=\mathrm{O}$, enquanto que a amida III apresenta grande contribuição na vibração de deformação $\mathrm{N}-\mathrm{H}$ no plano e pequena contribuição do estiramento C-N. 
$\mathrm{Na}$ tabela 3 é mostrado o intervalo em que aparecem as freqüências Raman dos modos $v(\mathrm{C}=\mathrm{O})$ da amida I e $\delta(\mathrm{NH})$ da amida III, para as proteínas contendo estruturas secundárias em $\alpha$-hélice, folhas- $\beta$ e ao acaso.

Tabela 3. Intervalo entre as freqüências Raman dos modos $v(\mathrm{C}=0)$ da amida I e $\delta(\mathrm{NH})$ da amida III, para as proteínas contendo estruturas secundárias em $\alpha$-hélice, folhas- $\beta$ e ao acaso (Grdadolnik,2001).

\begin{tabular}{ccc}
\hline Conformação & Amida I $\left(\mathbf{c m}^{-1}\right)$ & Amida III $\left(\mathbf{c m}^{-1}\right)$ \\
\hline$\alpha$-Hélice & $1645-1660$ & $1265-1300$ \\
\hline Folhas $\beta$ & $1665-1680$ & $1230-1240$ \\
\hline Ao acaso & $1660-1670$ & $1240-1260$ \\
\hline
\end{tabular}

Estes valores estão bem próximos aos valores encontrados no espectro Raman da solução de albumina bovina.

Estes intervalos espectrais característicos das amidas I e III resultaram de estudos Raman detalhados sobre polipeptídeos modelos, homopolipeptídeos e proteínas de conformação bem conhecida, onde se verificou a correlação entre freqüência e estrutura.

Uma banda intensa na região de $900-1000 \mathrm{~cm}^{-1}$, atribuída ao estiramento $C_{\alpha}-C-N$, também é sensível à conformação.

Proteínas contendo ligação dissulfeto, CCSSCC, apresentam banda Raman característica, relativamente intensa, na região $500-800 \mathrm{~cm}^{-1}$, atribuída ao modo de estiramento - S-S-. Existe uma correlação entre esta freqüência e a conformação. Assim, freqüências de $v(S-S)$ em 510, 525 e $540 \mathrm{~cm}^{-1}$ são esperadas quando os dois sítios trans em relação aos átomos de enxofre são ocupados, respectivamente, por: 2 átomos de hidrogênio, um hidrogênio e um carbono, ou 2 átomos de carbono.

Os grupos cistina e metionina, em proteínas, dão origem a vibrações de estiramento C-S na região de $600-750 \mathrm{~cm}^{-1}$ (Sturat, 1997).

A albumina nativa contém predominantemente estruturas $\alpha$-hélice, caracterizada por fortes picos de abundância em $1654 \mathrm{~cm}^{-1}$ e $1000 \mathrm{~cm}^{-1}$. Estes resultados estão de acordo com o trabalho realizado por Chen et. al., 1975. 
A variação na intensidade destes picos está relacionada com o conteúdo das estruturas de $\alpha$-hélice.

Analisando a figura 7, observou-se que após a liofilização da albumina bovina ocorreram alterações significativas nas estruturas de $\alpha$-hélice e também nas estruturas folhas $\beta$, atribuídas à faixa espectral entre 1620 a $1640 \mathrm{~cm}^{-1}$.

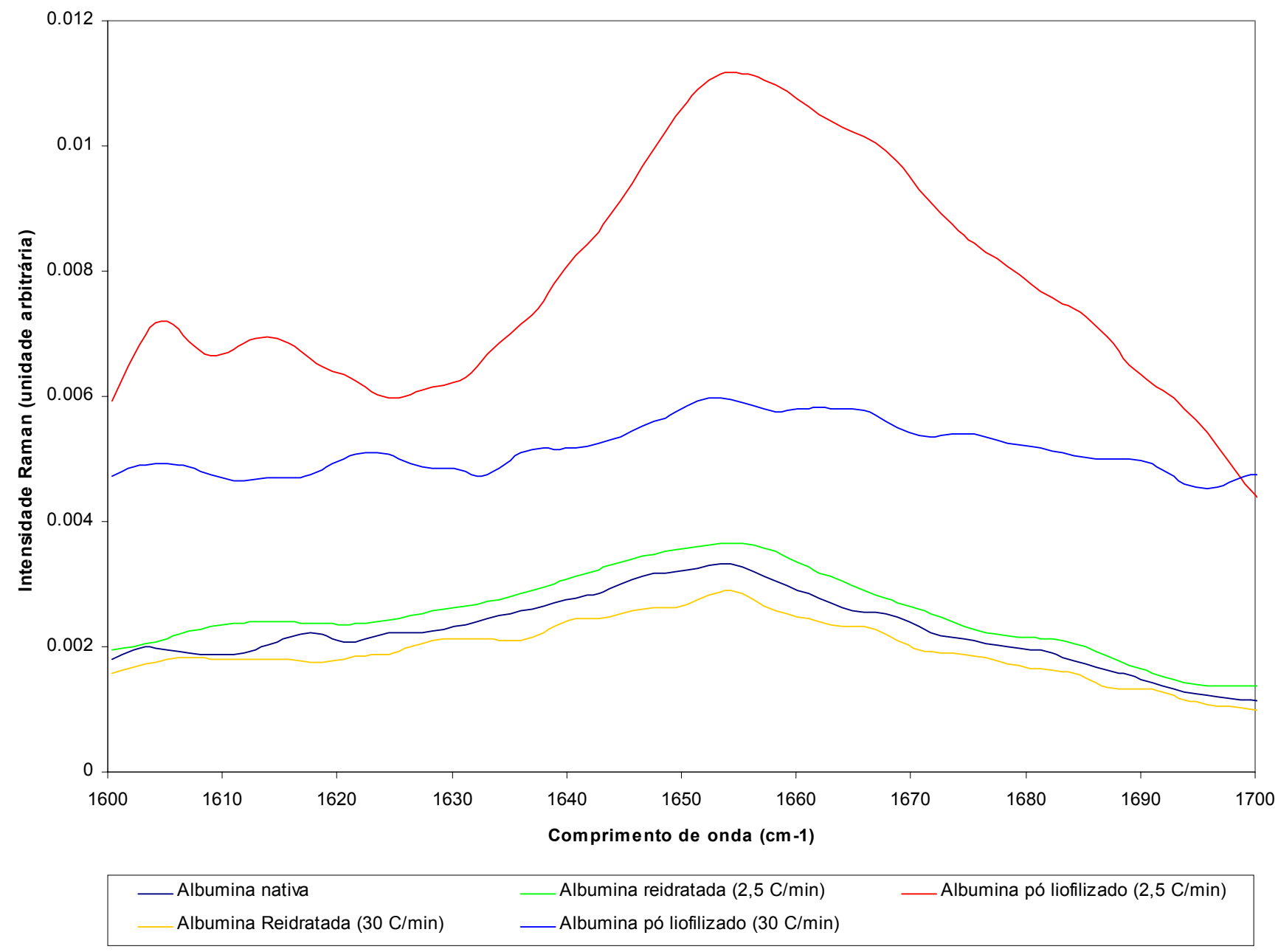

Fig.7. Espectro Raman da albumina bovina (liofilizada e reidratada) na região Amida I (conteúdo e posição das estruturas $\alpha$-hélice).

A freqüência destas bandas depende da força de ligação das pontes de hidrogênio na estrutura das folhas $\beta$ e também do tipo de ligação dos dipolos de transição.

Analisando a figura 8, a diferença na intensidade das estruturas $\alpha$ hélice $\left(1654 \mathrm{~cm}^{-1}\right.$ e $\left.1000 \mathrm{~cm}^{-1}\right)$ está diretamente relacionada com o nível de desdobramento protéico e agregação. 


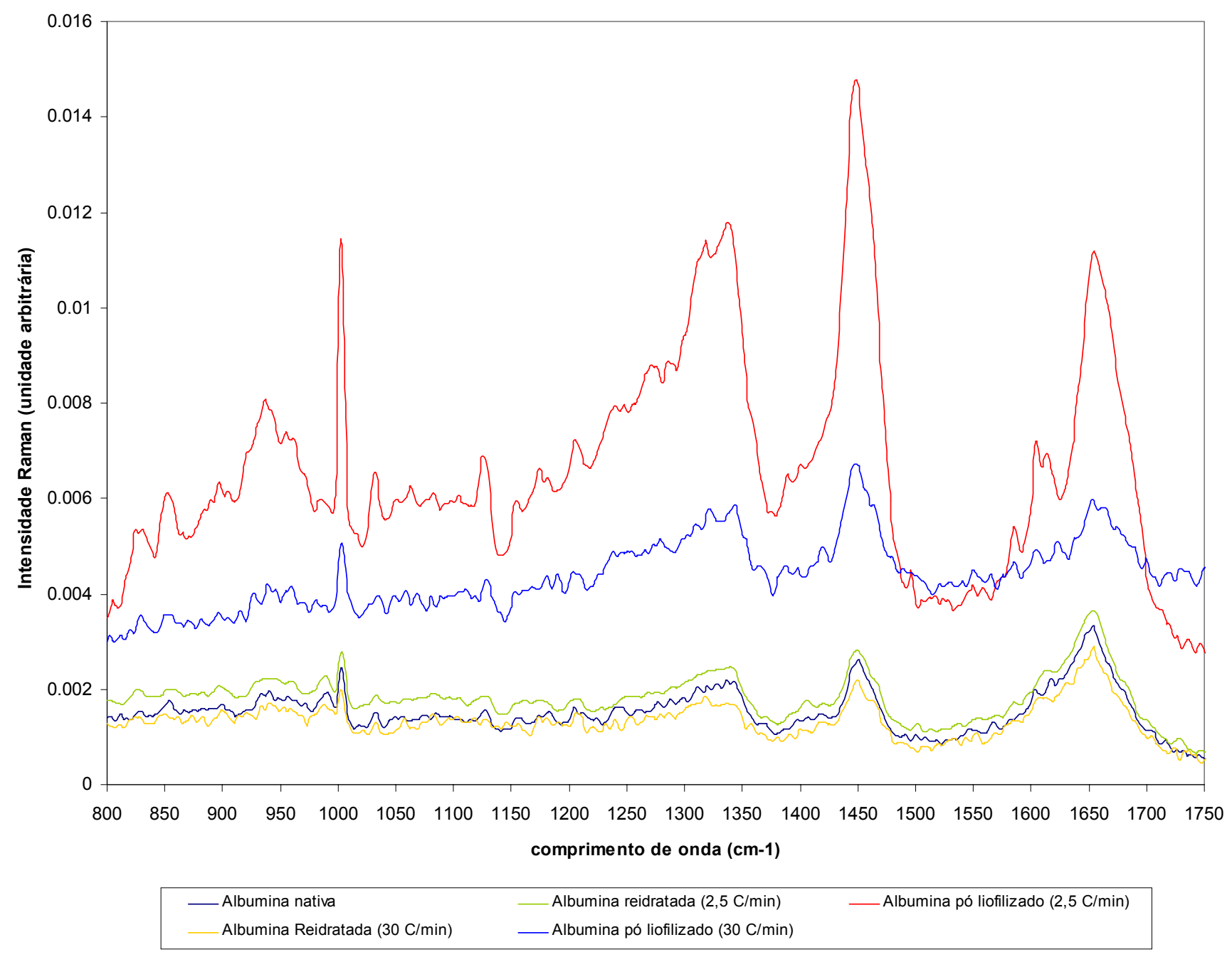

Fig.8. Espectro Raman da albumina bovina (liofilizada e reidratada).

A agregação protéica induzida pela temperatura também está associada com a formação de estruturas folhas $\beta$ antiparalelas representadas pela banda $1623 \mathrm{~cm}^{-1}$.

A albumina liofilizada com taxa de congelamento de $2,5^{\circ} \mathrm{C} / \mathrm{min}$ apresentou maior alteração estrutural quando comparada à albumina liofilizada com taxa de congelamento de $30^{\circ} \mathrm{C} / \mathrm{min}$.

Nota-se bruscas diferenças nas intensidades das estruturas de $\alpha$-hélice principalmente nas bandas 1654 e $1000 \mathrm{~cm}^{-1}$.

Entretanto, após a reidratação a albumina volta a apresentar a conformação estrutural original.

Quando comparada com a albumina liofilizada com taxa de congelamento de $2,5^{\circ} \mathrm{C} / \mathrm{min}$, a albumina congelada em nitrogênio líquido 
apresentou uma melhor recuperação do estado nativo. Provavelmente, o congelamento rápido impediu o crescimento abrangente dos cristais de gelo na crioconcentração da proteína, retardando substancialmente as alterações estruturais da albumina bovina.

A figura 9 mostra o estiramento das pontes de dissulfeto caracterizadas pelas bandas compreendidas entre $500 \mathrm{a} 800 \mathrm{~cm}^{-1}$.

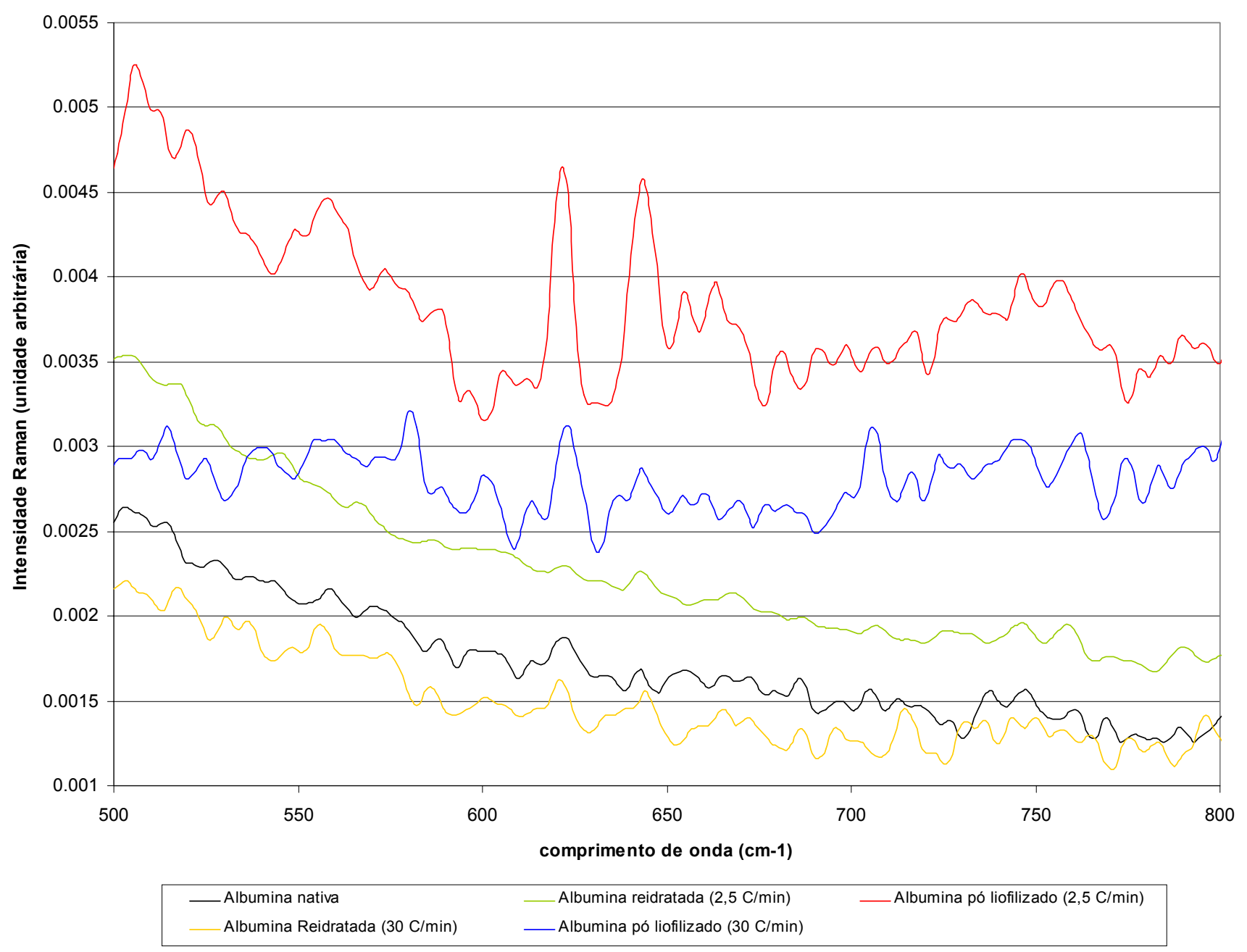

Fig.9. Espectro Raman da albumina bovina (liofilizada e reidratada) na região das pontes de dissulfeto.

A espectroscopia Raman vem sendo empregada extensivamente para a determinação da conformação das pontes de dissulfeto (S-S) em proteínas e polipeptídeos, pois a freqüência atribuída ao estiramento do modo S-S é sensível a esta conformação (Nakamura et. al., 1997). 
Podemos observar que a albumina liofilizada com taxa de congelamento de $2,5^{\circ} \mathrm{C} / \mathrm{min}$ apresentou um maior grau de estiramento e desordem estrutural relacionados às pontes de dissulfeto quando comparada com a albumina congelada por nitrogênio líquido.

Mesmo após a reidratação a albumina não foi capaz de adquirir sua conformação estrutural original.

Em uma visão geral dos resultados, observou-se uma aparente discrepância entre os teores de umidade das amostras liofilizadas, a qual pode ser explicada pelas alterações estruturais observadas nas amostras liofilizadas após o congelamento lento sugerindo portanto que o congelamento lento favoreceu a eliminação da água estrutural da albumina bovina alterando seu estado conformacional.

Após o estudo realizado com a albumina nativa prosseguiu-se com as análises da albumina bovina modificada com o metoxi-polietilenoglicol.

As figuras 10,11 e 12 representam o mapeamento térmico da albumina bovina com taxas de PEGuilação 1:0,25, 1:0,5 e 1: 1 respectivamente.

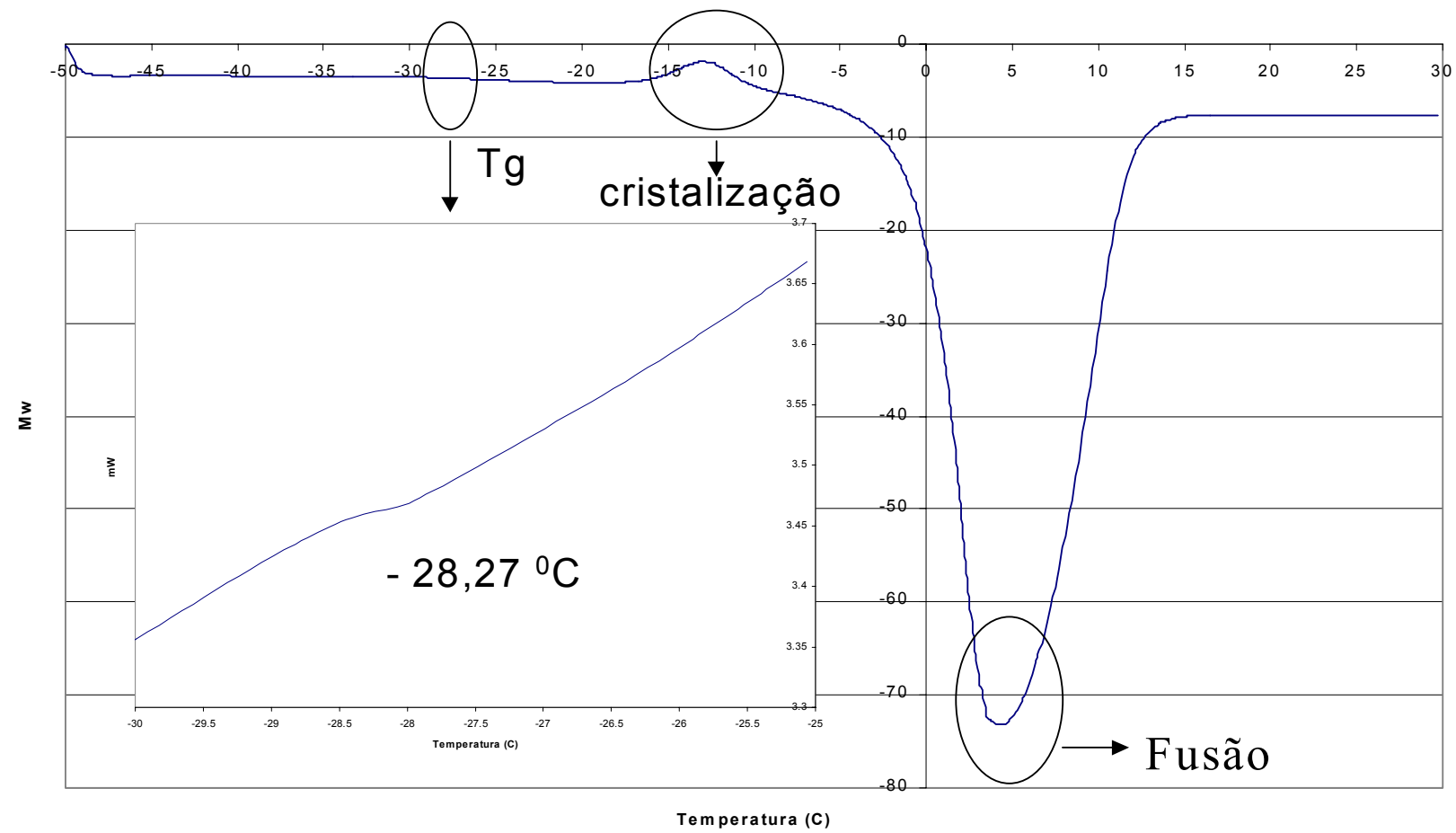

Fig.10. Análise térmica por DSC da solução BSA-PEG $(1: 0,25)$. O gráfico ilustra os eventos ocorridos durante o aquecimento da solução congelada. 
cristalização

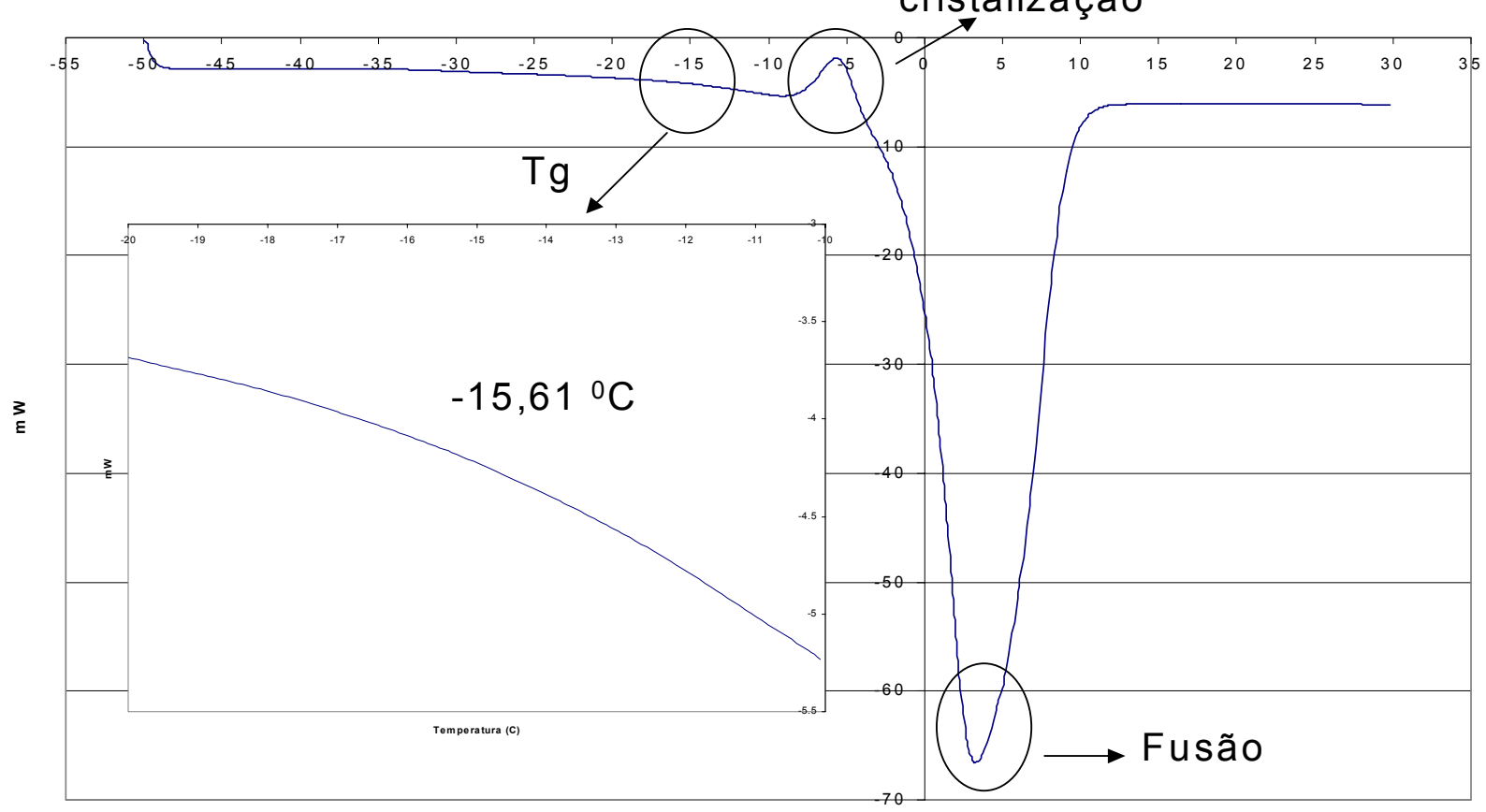

Temperatura (C)

Fig.11. Análise térmica por DSC da solução BSA-PEG (1:0,5). O gráfico ilustra os eventos ocorridos durante o aquecimento da solução congelada.

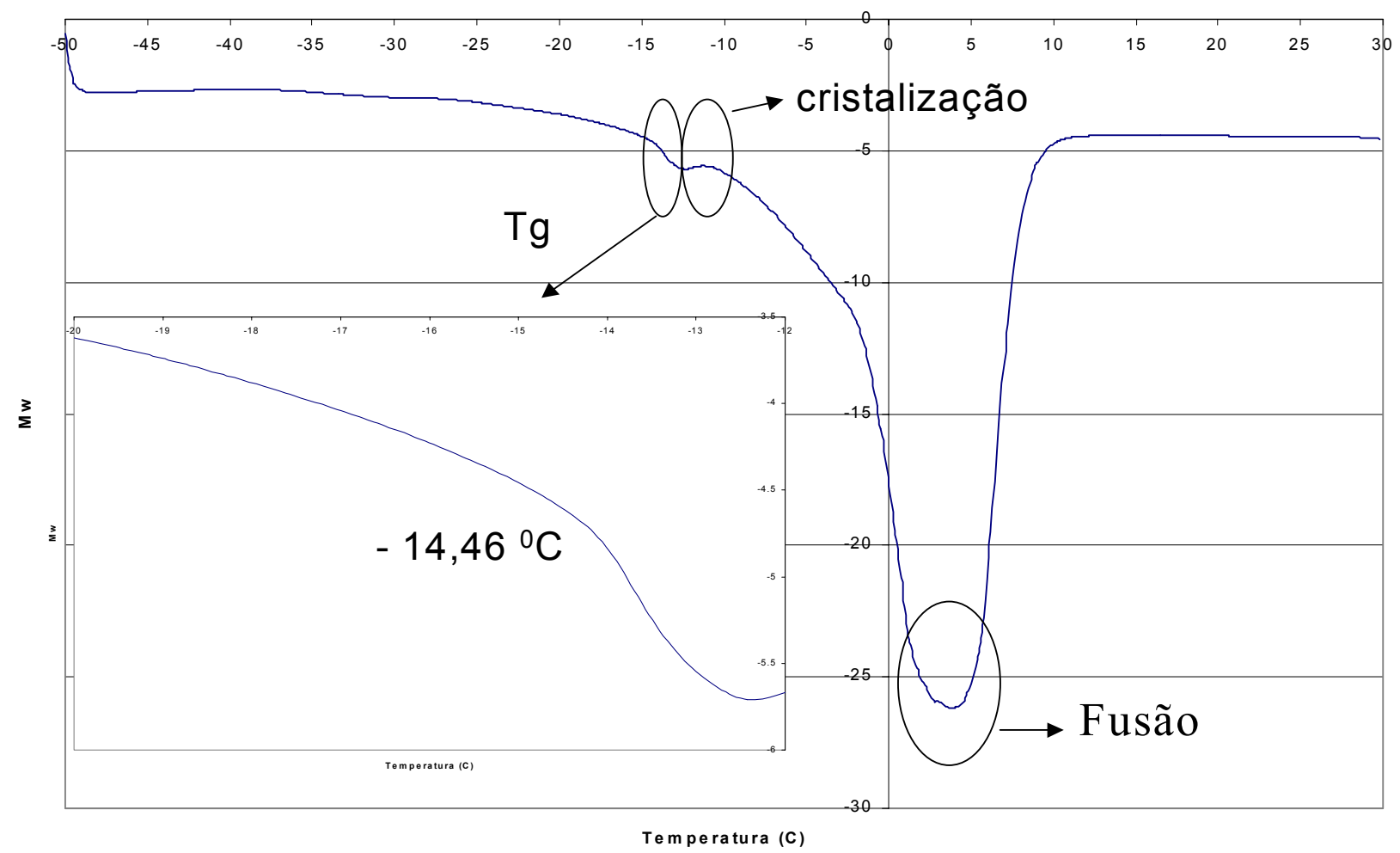

Fig.12. Análise térmica por DSC da solução BSA-PEG (1:1). O gráfico ilustra os eventos ocorridos durante o aquecimento da solução congelada. 
Todas as amostras apresentaram um declive endotémico referente a uma transição de segunda ordem denominada Tg. Após a Tg observou-se um pico exotérmico referente à cristalização de alguns componentes da solução de BSA-PEG, como por exemplo, os sais do tampão da solução e a cristalização parcial do próprio polietilenoglicol. As amostras de BSA-PEG em diferentes taxas de PEGuilação apresentaram um pico endotérmico de fusão entre 3 e $6{ }^{\circ} \mathrm{C}$.

As liofilizações da BSA-PEG 1:0,25 e 1:0,5 foram conduzidas sob as mesmas condições de processo (temperatura, pressão e tempo).

$\mathrm{Na}$ figura 13, não observou-se nenhuma diferença relacionada ao comportamento do material durante a liofilização.

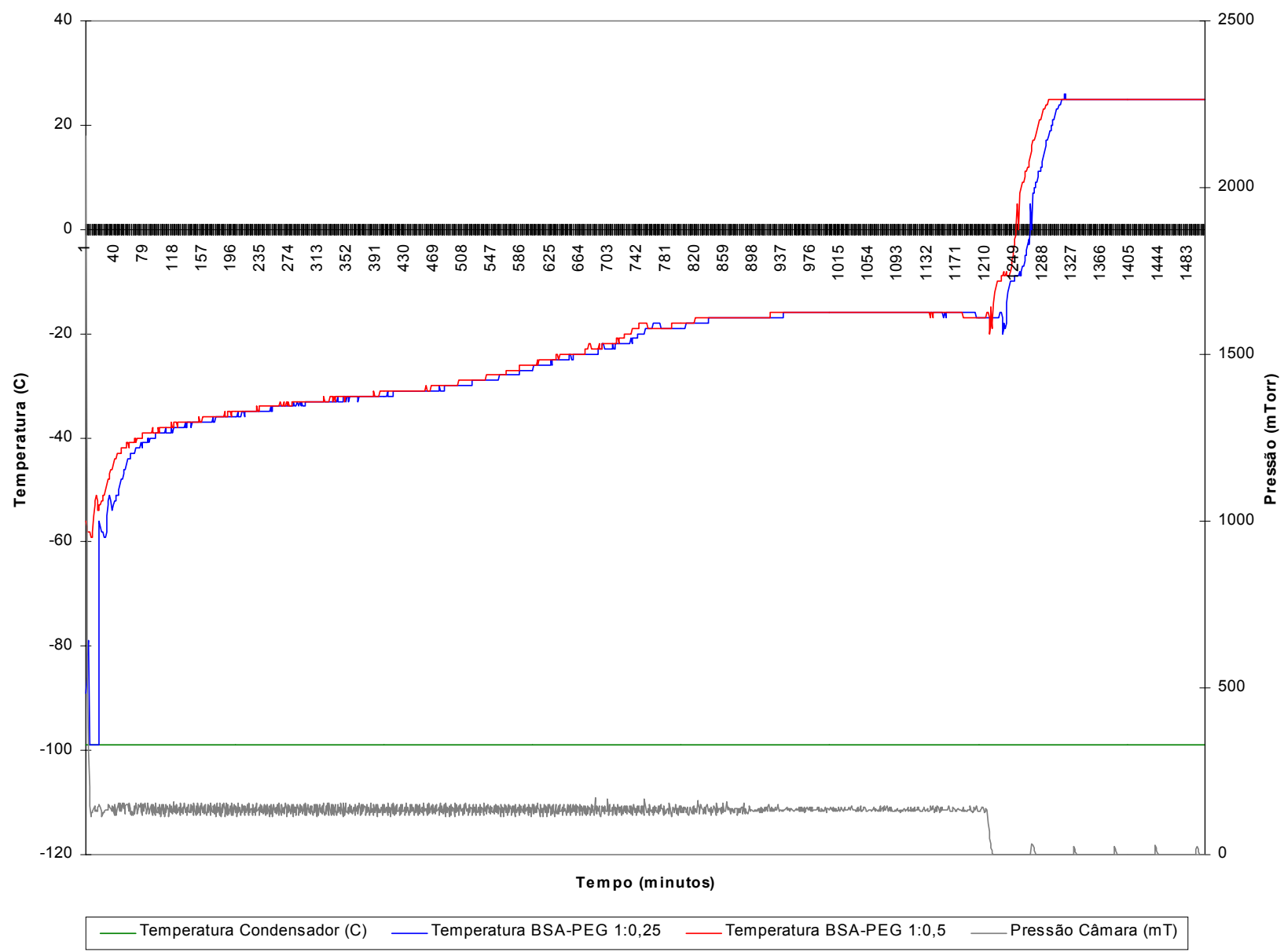

Fig.13. Comparação entre as curvas de liofilização das soluções BSA-PEG (1:0,25) e (1:0,5). As soluções apresentaram comportamento semelhante durante a secagem. 
As figuras 14 e 15 representam o mapeamento térmico por DSC do pó liofilizado da BSA-PEG 1:0,25 e 1:0,5 respectivamente. Observou-se um aumento no valor da Tg do material. A BSA-PEG 1:0,25 apresentou um pico na faixa de $57{ }^{\circ} \mathrm{C}$ relacionado à decomposição do material durante o aquecimento da amostra. O mesmo evento não foi observado durante o aquecimento da BSA-PEG 1:0,5. A BSA-PEG após a PEGuilação na taxa 1:1 comportou-se como um material gelatinoso, impedindo a sublimação da água durante a secagem, provocando o colapso do material. Não foi possível a continuidade dos estudos da BSA-PEG 1:1 devido às dificuldades encontradas durante a liofilização do material.

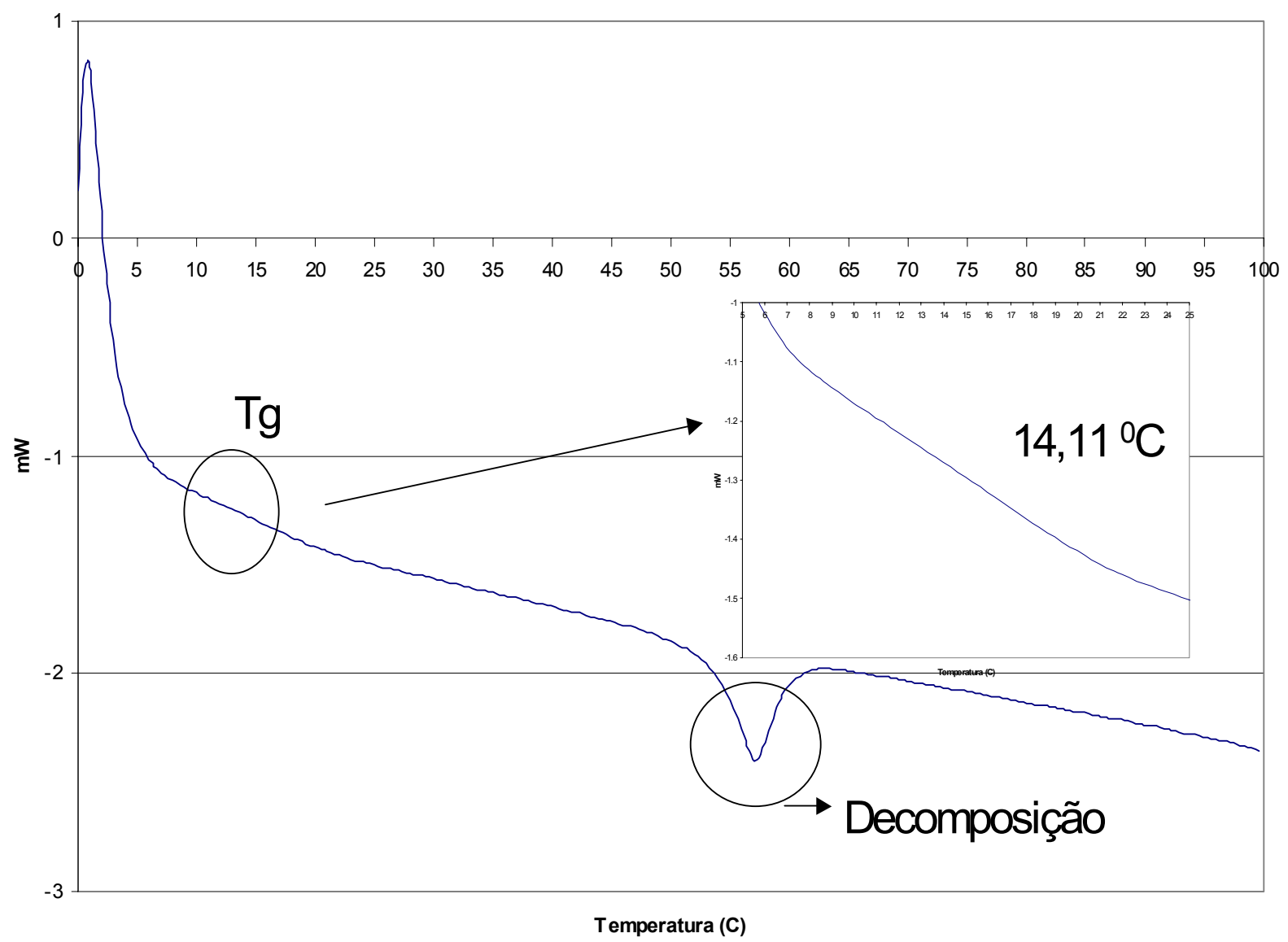

Fig.14. Análise térmica por DSC da BSA-PEG (1:0,25) pó liofilizado. O gráfico ilustra o evento da Tg durante o aquecimento da amostra. Observou-se um pico $\left(57^{\circ} \mathrm{C}\right)$ referente à decomposição da amostra. Umidade residual ( $6,4 \%)$. 


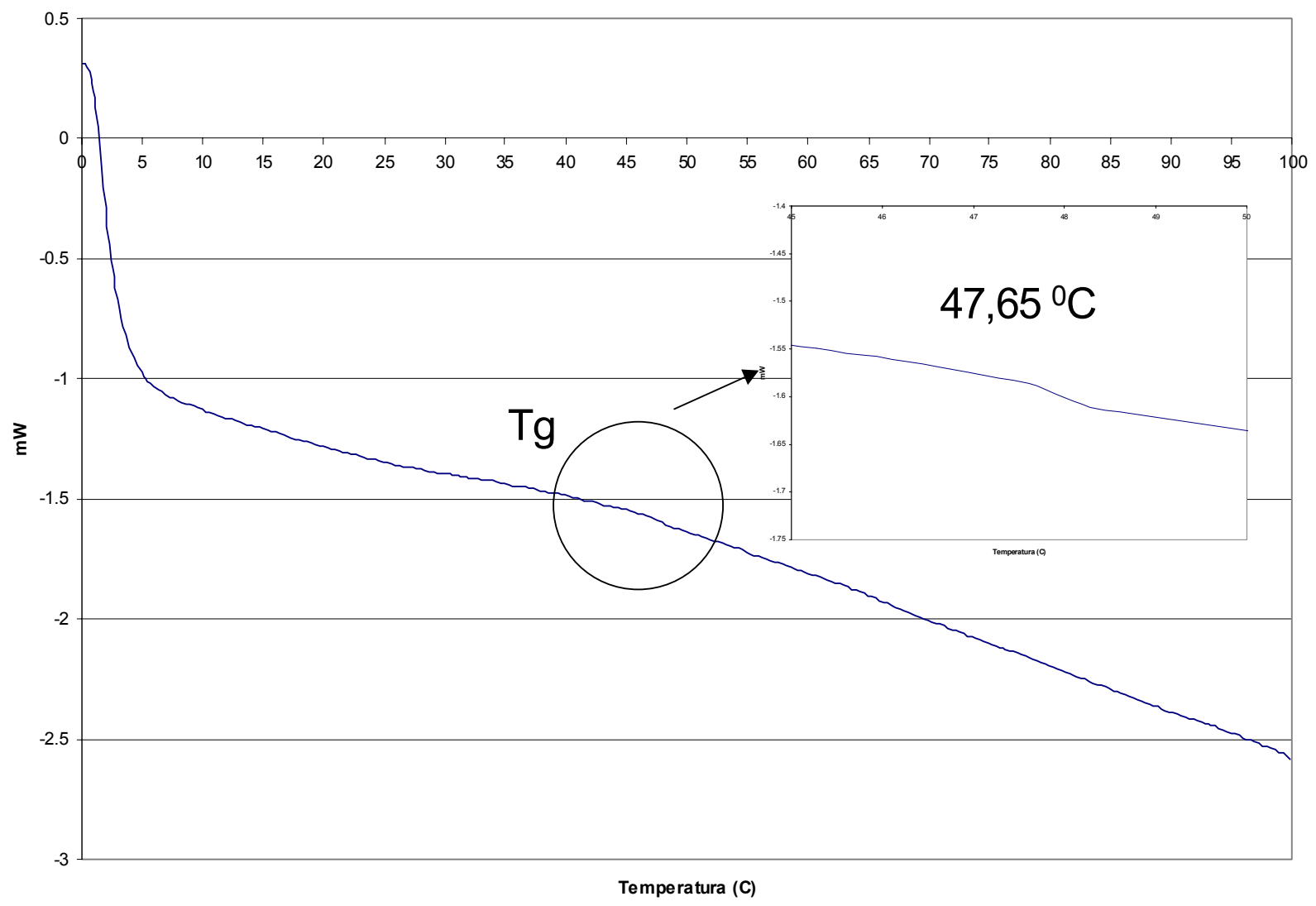

Fig.15. Análise térmica por DSC da BSA-PEG $(1: 0,5)$ pó liofilizado. O gráfico ilustra o evento da Tg durante o aquecimento da amostra. Umidade residual ( $5,3 \%$ ).

Após a secagem do material, realizou-se a determinação do teor de umidade residual das amostras.

Na figura 16 podemos observar uma diferença no conteúdo de umidade residual em relação às diferentes taxas de PEGuilação. Quanto maior a taxa de PEGuilação utilizada, maior a quantidade de sítios hidrofílicos ocupados, consequentemente menor a retenção de água pelo sistema. 


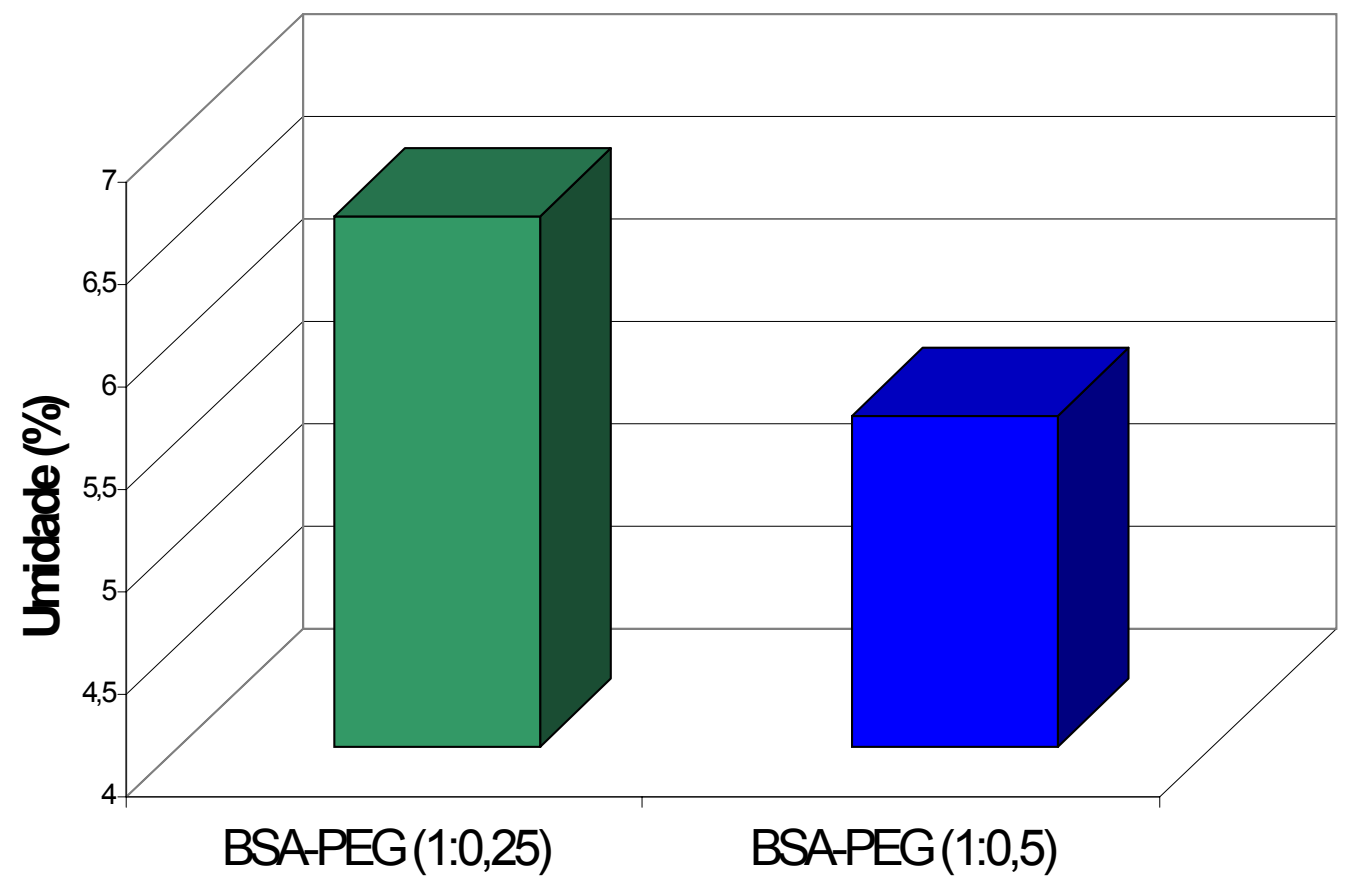

Fig.16. Comparação dos valores de umidade residual da BSA-PEG pó liofilizado em diferentes taxas de PEGuilação.

A figura 17 mostra que os valores de pH da BSA-PEG 1:0,25 e 1:0,5 não apresentaram diferenças significativas após a liofilização e reidratação (desvio padrão : 0,016). Entretanto observou-se uma diferença nos valores de $\mathrm{pH}$ entre as amostras com diferentes taxas de PEGuilação. 


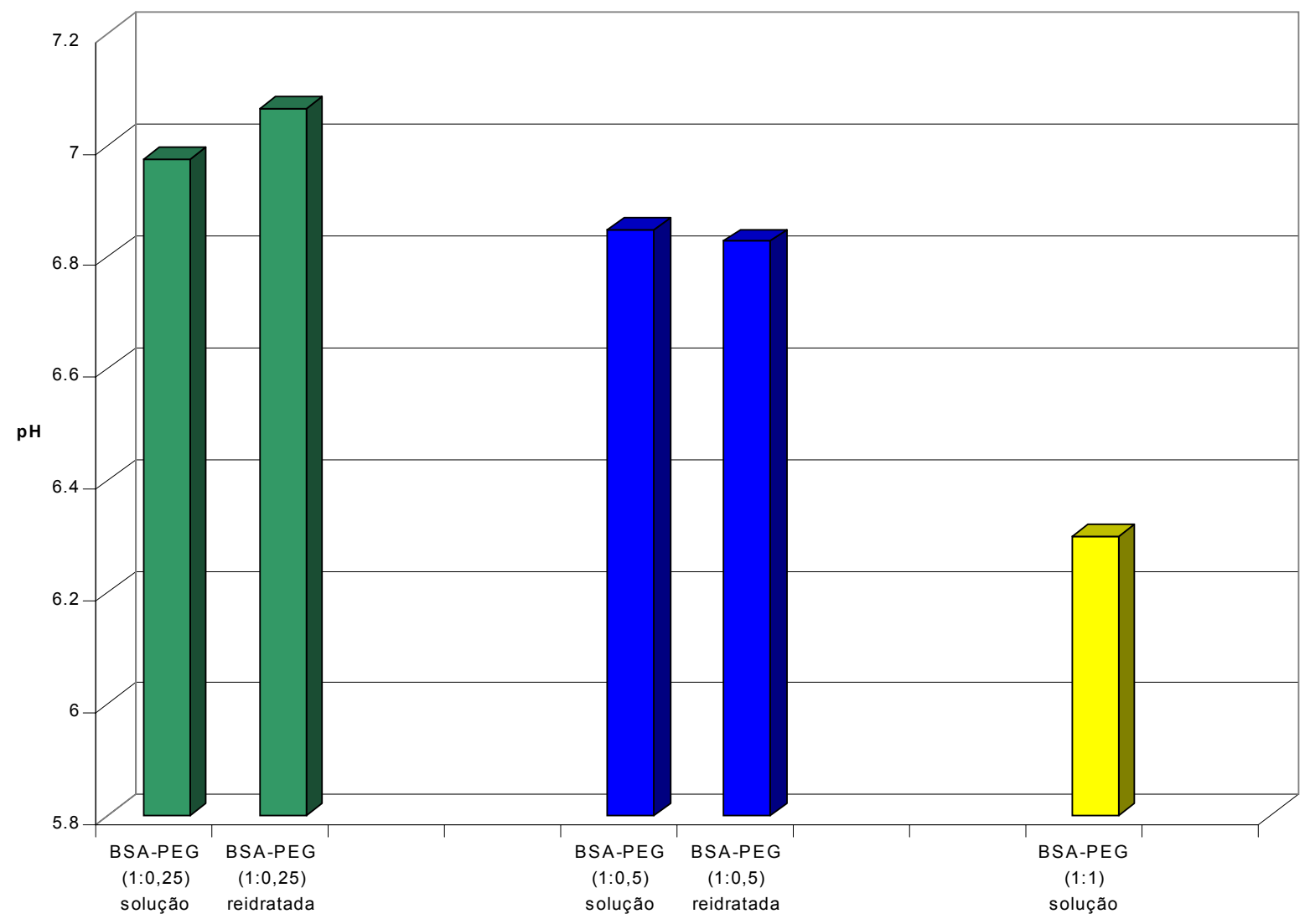

Fig.17. Comparação dos valores de $\mathrm{pH}$ das soluções de BSA-PEG em diferentes taxas de PEGuilação.

Analisando a figura 18 podemos observar que a modificação da albumina bovina com o metoxi-polietilenoglicol provocou alterações estruturais na proteína devido às diferentes intensidades e localizações dos picos de absorbância no espectro Raman.

Notou-se uma perda na estrutura $\alpha$-hélice indicado pela diminuição de intensidade na banda $1654 \mathrm{~cm}^{-1}$.

A BSA-PEG 1:0,25 apresentou uma menor variação nas estruturas $\alpha$ hélice $\left(1654 \mathrm{~cm}^{-1}\right)$ em relação à BSA-PEG. 1:0,5 e 1:1.

Ainda na região da Amida III, as bandas entre 1230 e $1240 \mathrm{~cm}^{-1}$, atribuídas às estruturas folhas- $\beta$ também apresentaram alterações espectrais, tanto na posição quanto na intensidade, após a modificação com o PEG. 
O aumento de intensidade nas bandas relacionadas às estruturas de folhas $\beta$ é um sinal característico de agregação protéica, induzida pelo aumento das interações moleculares entre o grupo $\mathrm{H}^{+}$, pois estes grupos polares precisam satisfazer as necessidades de ligações de pontes de hidrogênio através das interações intra ou intermoleculares ocasionadas pela remoção da água.

A albumina bovina na forma nativa contém em sua estrutura uma maior quantidade de grupos hidrofílicos não disponíveis em relação à albumina Peguilada.

Podemos observar que quanto maior a quantidade de PEG ligada à albumina, menor é a manutenção da estrutura secundária, ocasionada pela baixa retenção de água pelos grupos hidrofílicos.

$\mathrm{Na}$ figura 19 podemos observar que o pó liofilizado da albumina bovina modificada com o PEG na proporção 1:0,25 apresentou uma melhor manutenção da estrutura secundária da proteína.

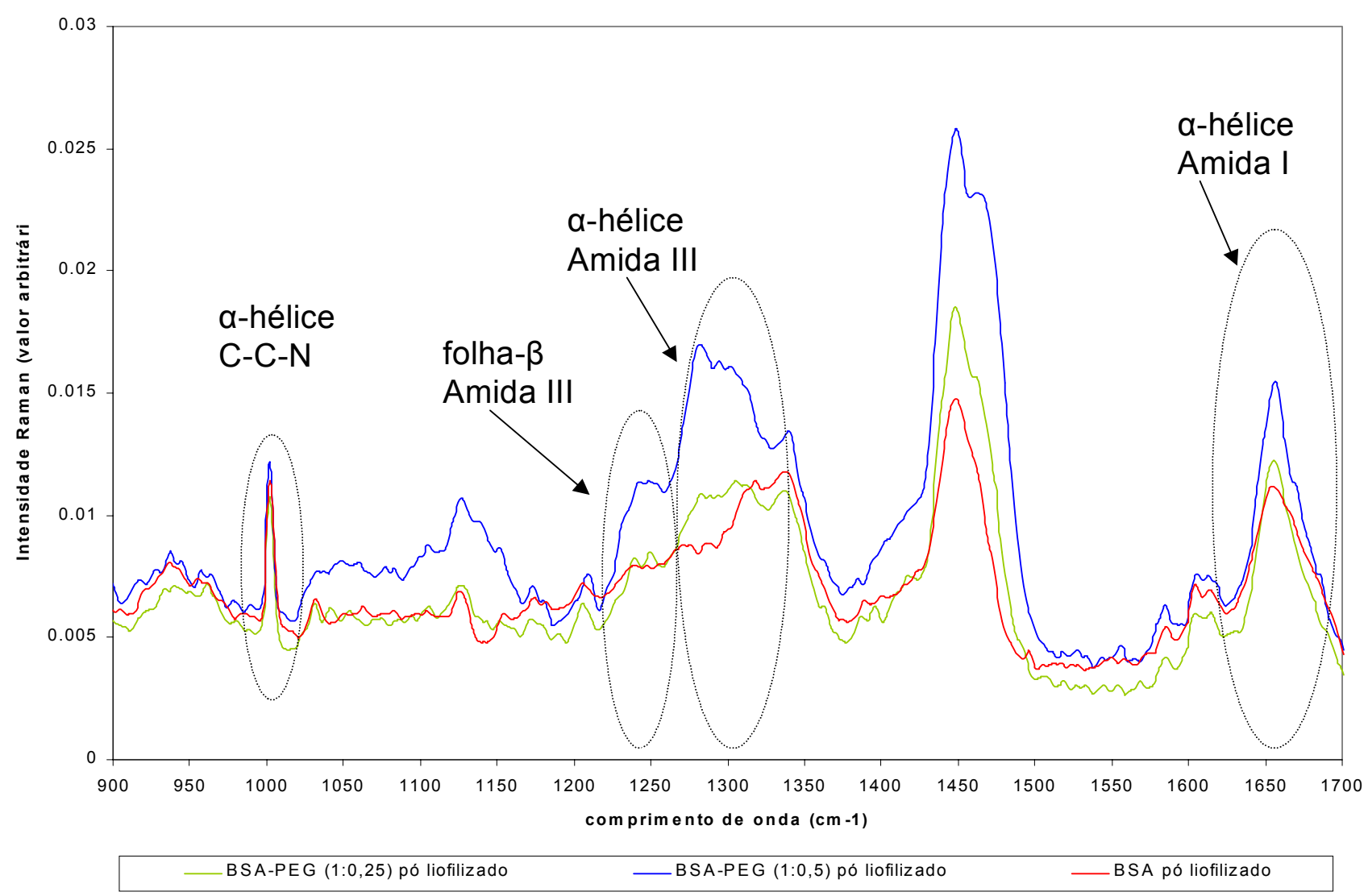

Fig.19. Comparação do espectro Raman do pó liofilizado entre a BSA nativa e a BSA-PEG em diferentes taxas de PEGuilação. 
Este resultado pode estar relacionado com uma menor taxa de alteração e/ou quebras das pontes de hidrogênio e forças de Van der Walls.

As figuras 20 e 21 mostram que a BSA-PEG $(1: 0,25)$ apresentou melhores resultados de manutenção estrutural, após a liofilização e reidratação quando comparada com a BSA-PEG $(1: 0,5)$.

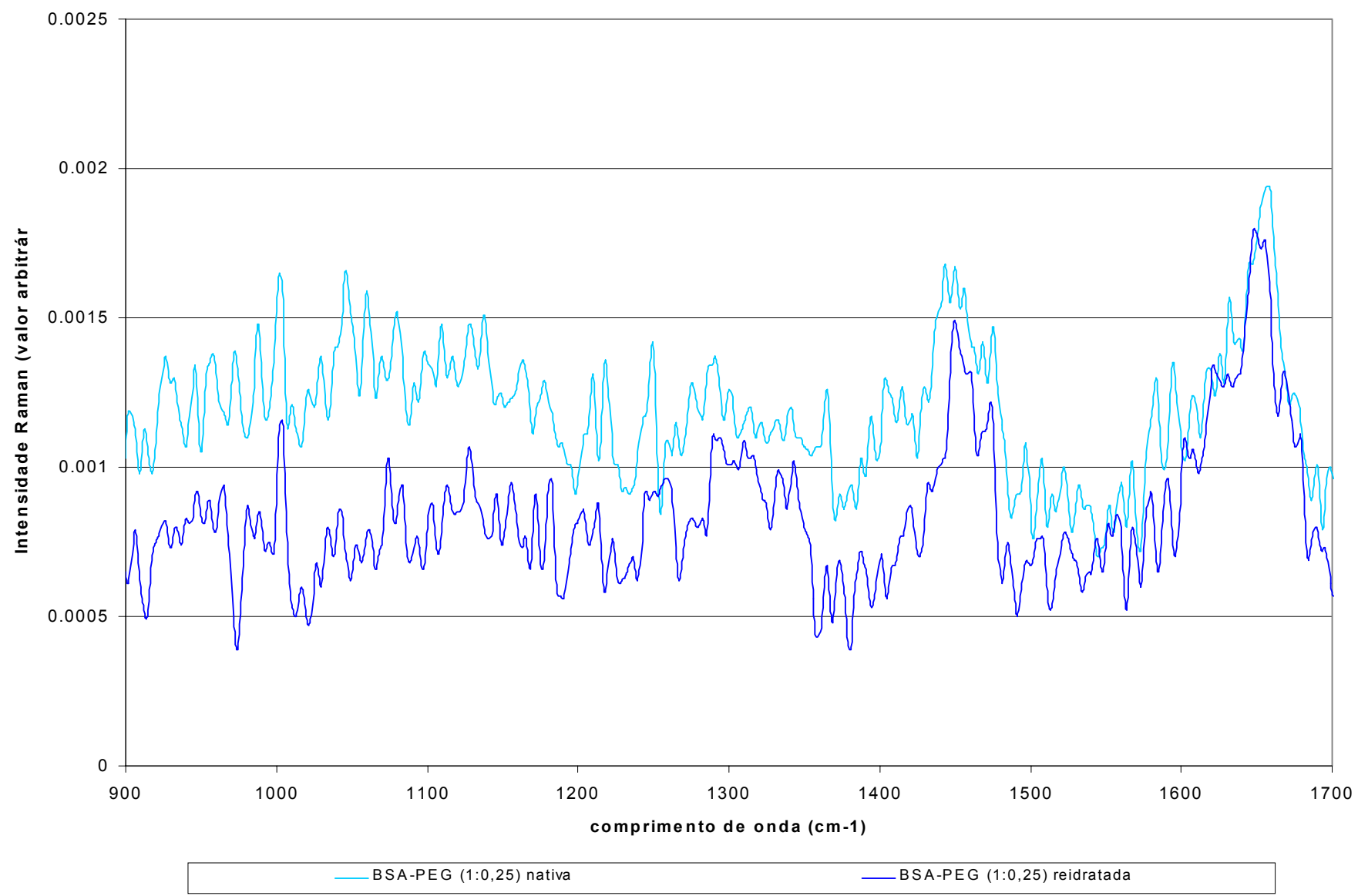

Fig.20. Comparação do espectro Raman entre as soluções de BSA-PEG $(1: 0,25)$ nativa e a BSAPEG $(1: 0,25)$ reidratada 


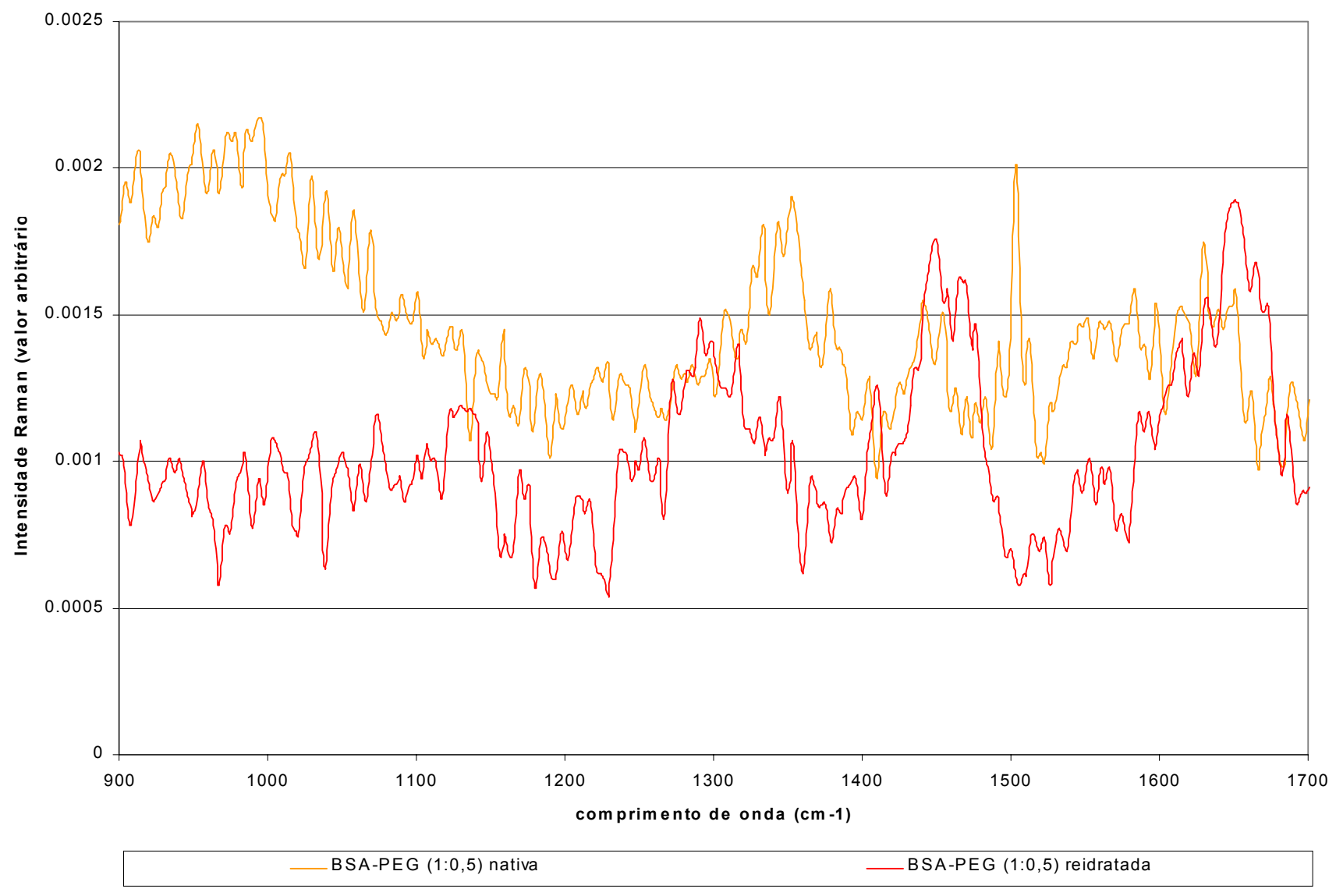

Fig.21. Comparação do espectro Raman entre as soluções de BSA-PEG $(1: 0,5)$ nativa e a BSAPEG $(1: 0,5)$ reidratada.

Três bandas 1620, 1630 e $1690 \mathrm{~cm}^{-1}$ atribuídas à vibração das folhas- $\beta$ antiparalelas sofreram diferentes níveis de alterações.

As regiões da amida I e III apresentaram alterações estruturais em diferentes níveis em relação às diferentes taxas de PEGuilação.

A manutenção da conformação estrutural da albumina bovina está diretamente relacionada com a retenção de água pelos grupos $\mathrm{NH}_{2}$ ligados à lisina.

A banda com comprimento de onda de $1000 \mathrm{~cm}^{-1}$ relacionada com estruturas $\alpha$-hélice (C-C-N) praticamente desapareceu após a modificação da BSA com o PEG na proporção 1: 0, 5.

Após a reidratação do pó liofilizado, a distribuição de intensidade na banda entre $1320-1340 \mathrm{~cm}^{-1}$ relacionadas às cadeias laterais alifáticas foi maior para a BSA-PEG $(1: 0,25)$.

As alterações espectrais induzidas pela liofilização na região da amida I são devidas ao desdobramento da proteína pela perda de água estrutural durante a liofilização. Os efeitos intrínsecos da remoção da água nas propriedades de 
oscilação nas ligações peptídicas, e, por conseguinte, no espectro infravermelho da proteína, foram tidos insignificantes por Prestrelski e outros (1998). Se os efeitos diretos de oscilação da remoção da água foram responsáveis pelas alterações espectrais induzidas pela secagem, então o espectro infravermelho de todas as proteínas deveria ser alterado para o mesmo grau no estado liofilizado, o que não é o caso.

Observou-se dois comportamentos diferentes da BSA-PEG com desdobramento estrutural no estado liofilizado:

- A BSA-PEG 1:0,25 recuperou boa parte da conformação original após reidratação (desdobramento reversível) ;

- Uma fração significativa das moléculas de BSA-PEG 1:0,5 agregaram-se com a reidratação (desdobramento irreversível).

Tem sido documentado com várias proteínas, que a prevenção da agregação e o restabelecimento da atividade após a reidratação correlaciona-se diretamente com a retenção da estrutura original no sólido seco ( Carpenter et. al., 1999).

Analisando as figuras 22 e 23 referentes aos resultados de transmitância das soluções de BSA e BSA-PEG pode-se observar que a conjugação BSA-PEG alterou a translucidez da solução em relação às diferentes taxas de PEGuilação. Quanto maior a concentração de PEG utilizada na modificação, menor a transmitância da solução. Porém não observou-se diferenças de transmitância após a reidratação das amostras. Não foram realizadas análises de viscosidade, porém observou-se um aumento de viscosidade da solução conforme o aumento de PEG utilizado para a modificação da proteína.

$\mathrm{Na}$ figura 24 observou-se que não houve diferença de cor no pó liofilizado entre as amostras modificadas com diferentes taxas de metoxipolietilenoglicol. 


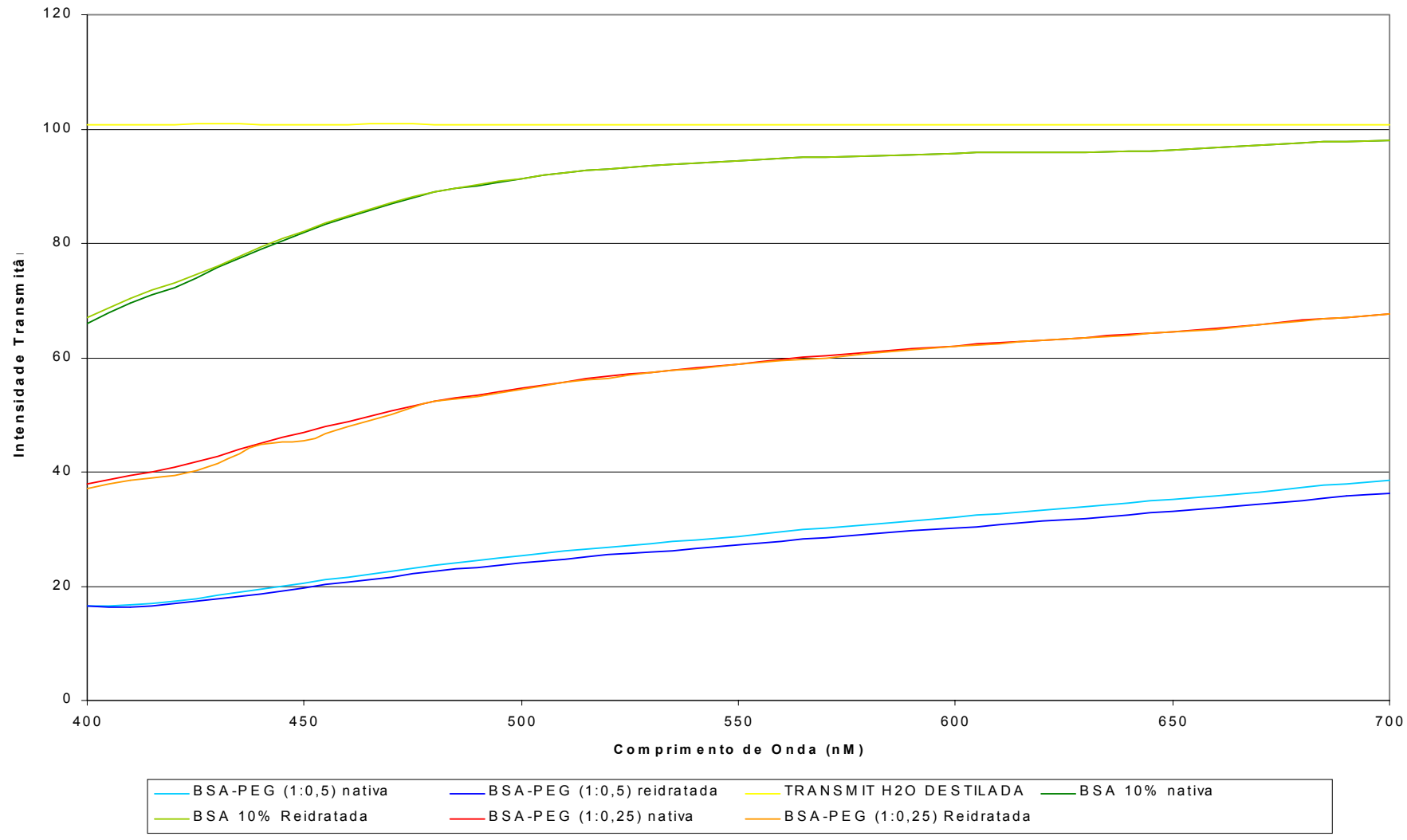

Fig.22. Comparação entre os comprimentos de ondas na transmitância da luz da BSA nativa e BSA-PEG solução em diferentes taxas de PEGuilação.

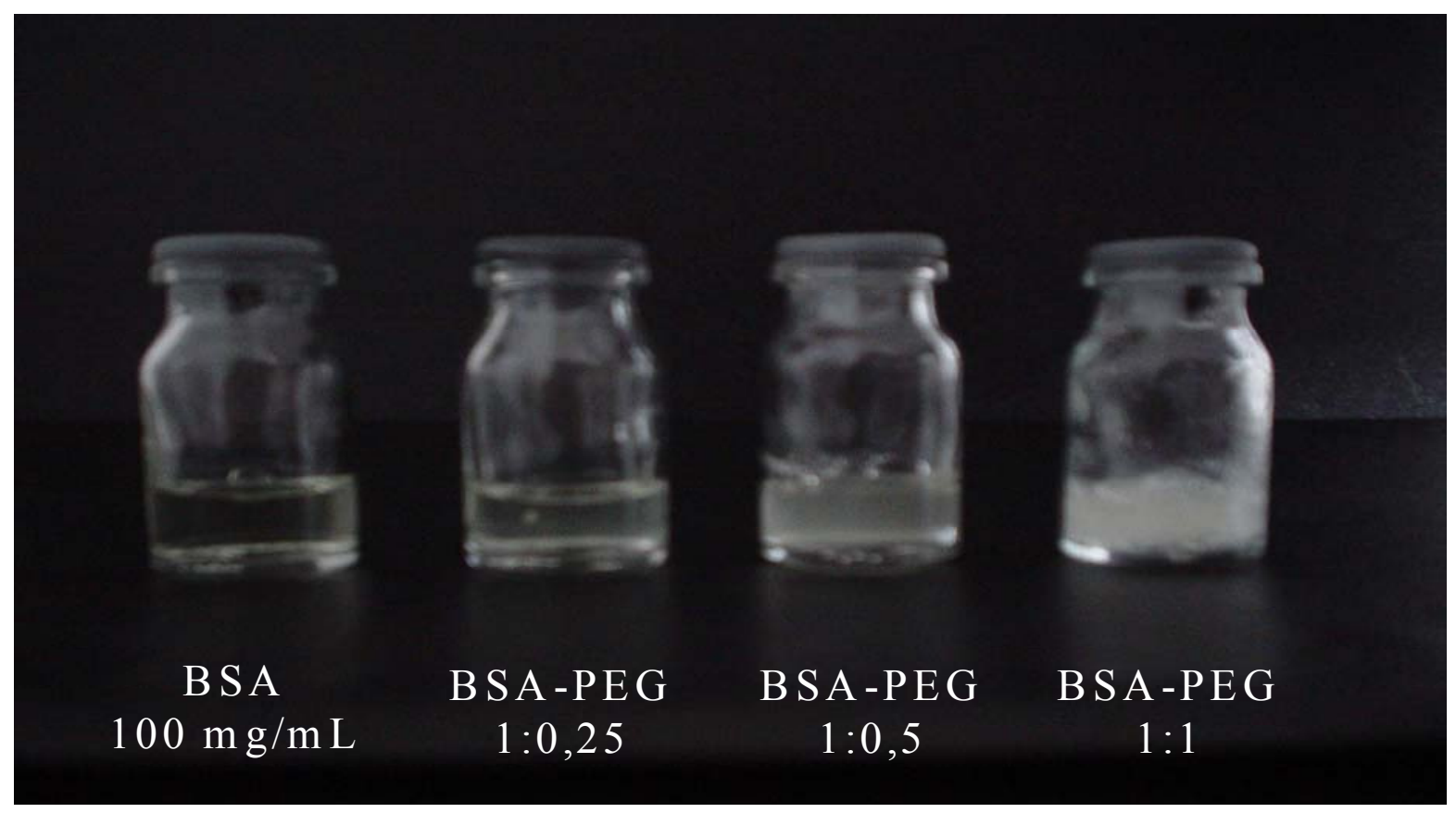

Fig.23. Alteração na translucidez da solução de albumina bovina após a modificação com o metoxipolietilenoglicol. 


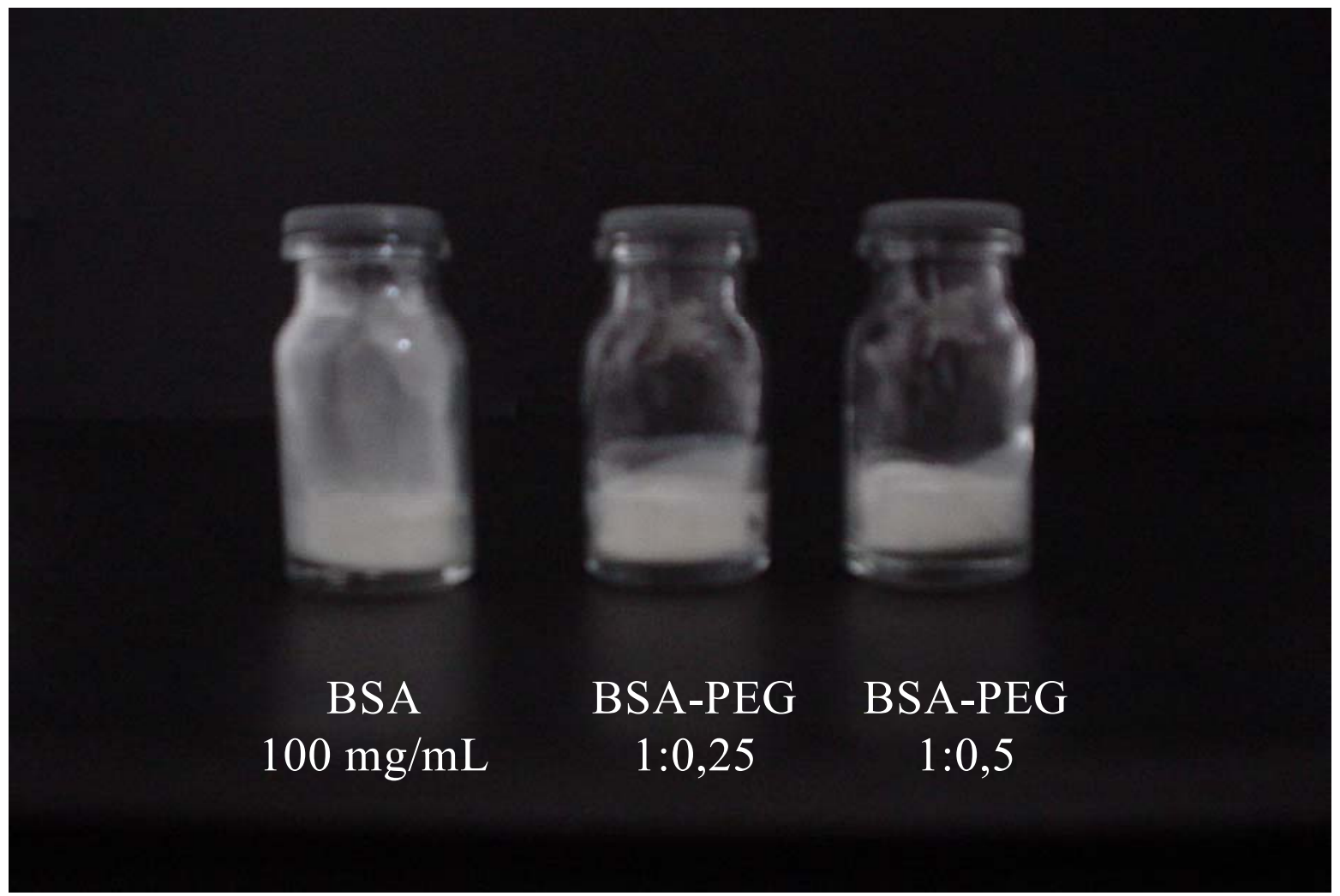

Fig.24. Pó liofilizado da albumina bovina modificada com diferentes taxas de metoxi-polietilenoglicol. 


\section{CONCLUSÕES}

O presente trabalho permitiu estabelecer as seguintes conclusões:

- A liofilização com taxa de congelamento de $30^{\circ} \mathrm{C} / \mathrm{min}$ apresentou menores oscilações espectrais nas regiões da amida I, III e pontes de dissulfeto favorecendo a manutenção da conformação estrutural da proteína;

- A albumina bovina liofilizada com taxa de congelamento de 30 ${ }^{0} \mathrm{C} / \mathrm{min}$. apresentou desdobramento estrutural durante a liofilização, mas recuperou a conformação original após a reidratação (desdobramento reversível);

- A albumina bovina liofilizada com taxa de congelamento de 2,5 ${ }^{0} \mathrm{C} / \mathrm{min}$. apresentou desdobramento estrutural durante a liofilização e agregação após a reidratação (desdobramento irreversível), característica desfavorável em relação à manutenção da estrutura secundária da proteína ;

- O congelamento lento favoreceu a eliminação da água estrutural da albumina bovina nativa diminuindo o tempo de secagem durante a liofilização porém alterando a estrutura conformacional da molécula ;

- Após a modificação da albumina bovina com metoxi-polietilenoglicol, a BSA-PEG 1:0,25 apresentou um menor grau de alteração estrutural e conseqüentemente uma menor variação das características físicos-químicas da proteína quando comparada com a BSA-PEG 1:0,5.

- A modificação da albumina bovina com o metoxi-polietilenoglicol aumentou a temperatura de transição vítrea para a solução protéica e para o pó liofilizado otimizando as condições de liofilização e de armazenamento abaixo da temperatura de colapso do material;

- A liofilização não alterou a cor do pó liofilizado, independente da taxa de modificação com o PEG utilizada favorecendo as características relacionadas à elegância farmacêutica em um produto.

- Todas as temperaturas críticas para a liofilização da albumina bovina modificada com o PEG para as taxas de 1:0,25, 1:0,5 e 1:1 foram determinadas;

- O controle do teor de umidade residual do pó liofilizado é importante para a manutenção da estrutura secundária da proteína;

- A regeneração da estrutura nativa da proteína, após a reidratação, depende da manutenção de boa parte de sua água estrutural. 
Com o objetivo de se manter o efeito terapêutico (redução da imonogenicidade, aumento da $\mathrm{T} / \mathrm{I}_{2}$ (meia vida da droga no organismo) associado a manutenção das propriedades físico-químicas e estruturais da proteína, recomenda-se um estudo mais aprofundado, para a determinação da taxa ideal de modificação molecular com o PEG, visto que a modificação molecular da BSA resultou em diferentes níveis de alterações estruturais.

\section{REFERÊNCIAS BIBLIOGRÁFICAS}

ANCHOROQUY, T.J., CARPENTER, J.F., Polymers protect lactate dehydrogenase during freeze-drying by inhibiting dissociation in the frozen state, Arch. Biochem. Biophys., v. 332, p. 231-238, 1996.

CARPENTER, J. F., IZUTSU, K., RANDOLPH, T. W., Freezing- and dryinginduced perturbations of protein structure and mechanisms of protein protection by stabilizing additives, Freezing-Drying / Lyophilization of Pharmaceutical and Biological Products, edited by Louis Rey, 1999.

CARPENTER, J. F., PRESTRELSKI, S. J., DONG, A., European Jourmal of Pharmaceutics and Biopharmaceutics, v. 45, p. 231-238, 1998.

CARPENTER, J. F., PIKAL, M. J., CHANG, B. S., RANDOLPH, T. W., Rational design of stable lyophilized protein formulations: some practical advice, Pharmaceutical Research, v. 14, nº 8, p. 969-975, 1997.

CHANG, B.S., RANDALL, C., Use of subambient thermal analysis to optimize protein lyophilization, Cryobiology, v. 29, p. 632-638, 1992.

CHANG, B.S., KENDRICK, B.S., CARPENTER, J.F., Surface-induced denaturation of proteins during freezing and its inhibition by surfactants, J. Pharm. Sci., v. 85, p. 1325-1330, 1996. 
CHASE, D.B., RABOLT, J.F., Fourier Transform Raman Spectroscopy (from concept to experiment), Academic Press, 1994.

CHEN, T., OAKLEY, D.M.,Thermal analysis of proteins of pharmaceutical interest, Thermochimica Acta, v. 248, p. 229-244, 1995.

CHEN, M. C., LORD, R. C., Laser-Excited Raman Spectroscopy of Biomolecules.VIII. Conformational Study of Bovine Serum Albumin, Journal of the American Chemical Society, v. 98, p. 4-10, 1976.

ECKHARDT, B.M., OESWEIN, J.Q., BEWLEY, T.A., Effect of freezing on aggregation of human growth hormone, Pharm. Res., v. 8, p. 1360-1364, 1991.

FRANKS, F., Solid aqueous solutions, Pure Appl. Chem., v. 65, p. 2527-2537, 1993.

FRENCH,D.L., ARAKAWA, T., NIVEN, R.W., LI, T., FTIR investigation of hydration-induced conformational changes in spray-dried protein / trehalose powders. Pharm. Res., v.12 (Suppl.), S83, 1995.

GRDADOLNIK, J., Conformation of bovine serum albumin as a function of hydration monitored by infrared spectroscopy, The International Journal of Vibrational Spectroscopy, v. 6, Edition 1, 2001.

GRENNWALD, R. B., PEG drugs: an overview, Journal of Controlled Release, v.74, p.159-171, 2001.

GRIEBENOW, K., KLIBANOV, A. M. , Lyophilization-induced reversible changes in the secondary structure of proteins, Proc. Natl. Acad.Sci. USA 92, v. 1096910976, 1995.

HELLER, M.C., CARPENTER, J.F., RANDOLPH, T.W., Conformational stability of lyophilized PEGylated proteins in a phase-separating system, J. Pharm. Sci., v. 88, p. 58-64, 1999. 
HSU, C.C., NGUYEN, H.M., YEUNG, D.A, BROOKES, D.A., KOE, G.S., BEWLEY, T.A, PEARLMAN, R., Surface denaturation at solid-void interface - a possible pathway by which opalescent particulates form during the storage of lyophilized tissue-type plasminogen activator at high temperatures, Pharm. Res., v. 12, p. 69-77, 1995.

INADA, Y., FURUKAWA, M., SASAKI, H., KODERA, Y., HIROTO, M., NISHIMURA H., MATSUSHIMA, A., Biomedical and Biotechnological Applications of PEGand PM-Modified Proteins, TIBTECH MARCH, v.13, 1995.

KIM, A.I., AKERS, M.J., NAIL, S.L., The physical state of mannitol after freezedrying: effect of mannitol concentration, freezing rate, and a noncrystallizing cosolute, J. Pharm. Sci., v. 87, p. 931-935, 1998.

KODERA, Y., MATSUSHIMA, A., HIROTO, M., NISHIMURA, H., ISHII, A., UENO, T., INADA, Y., PEGylation of Proteins and Bioactive Substances for Medical and Technical Applications, Prog. Polym. Sci., v. 23, p. 1233-1271, 1998.

LAM, X.M., CONSTANTINO, H.R., OVERCASHIER, D.E., NGUYEN, T.H., HSU, C.C., Replacing succinate with glycocholate buffer improves the stability of lyophilized interferon- $\gamma$. Int. J. Pharm., v. 142, p. 85-95, 1996.

LI,S., NGUYEN, T., SCHONEICH, C., BORCHARDT, R.T., Aggregation and precipitation of human relaxin induced by metal-catalyzed oxidation. Biochemistry, v. 34, p. 5762-5772, 1995.

MURGATROYD, K., BUTLER, L. D., KINNARNEY, K., MONGER, P., Good Pharmaceutical Freeze-Drying Practice, edited by Peter Cameron, 1997.

NAKAMURA, K., ERA, S., OZAKI, Y., SOGAMI, M., HAYASHI, T., MURAKAMI, M., Conformational changes in seventeen cystine disulfide bridges of bovine serum albumin proved by Raman spectroscopy, Federation of European Biochemical Societies Letters, v. 417, p. 375-378, 1997. 
PIKAL, M.J., SHAH, S., The collapse temperature in freeze- drying: Dependence on measurement methodology and rate of water removal from the glassy state, Int. J. Pharm., v. 62, p. 165-186, 1990.

PIKAL, M.J., DELLERMAN, K., ROY, M.L., Formulation and stability of freeze-dried proteins: effects of moisture and oxygen on the stability of freeze-dried formulations of human growth hormone. Dev. Biol., v. 74, p. 21-37, 1991.

PRESTRESLKI, S.J., ARAKAWA, T., CARPENTER, J.F., Separation of freeze and drying- induced denaturation of lyophilized proteins by stress-specific stabilization: II.Structural studies using infrared spectroscopy, Arch. Biochem. Biophys., v. 303, p. 465-473, 1993.

PRESTRESLKI, S.J, TEDESCHI, N., ARAKAWA, T., CARPENTER, J.F., Dehydration-induced conformational changes in proteins and their inhibition by stabilizers, Biophys. J., v. 65, p. 661-671, 1993.

ROSS, Y., KAREL, M., Differential scanning calorimetry study of phase transitions affecting the quality of dehydrated materials, Biotechnol. Prog., v. 6 , p. 159$165,1990$.

ROSS, Y., Melting and Glass Transitions of Low Molecular Weight Carbohydrates, Carbohydrate Res., v. 238, p. 39-47, 1993.

STUART, B., Biological applications of infrared spectroscopy, Analytical Chemistry by Open Learning, 1997.

TE BOOY, M.P.W.M., RUITER, R.A., MEERE, A.L.J., Evaluation of the physical stability of freeze-dried sucrose-containing formulations by differential scanning calorimetry, Pharm. Res., v. 9, p. 109-115, 1992.

TOWNS, J. K., Moisture content in proteins: its effects and measurement, Journal of Chromatography A, v. 705, p. 115-127, 1995. 
VERONESE, F. M., Peptide and protein PEGylation: a review of problems and solutions, Biomaterials, v.22, p. 405-417, 2001.

WANG, W., Lyophilization and development of solid protein pharmaceuticals, International Journal of Pharmaceuticals, v. 203, p. 1-60, 2000.

WOLANEZYK, J.P., Relation between glass transition and stability of a frozen product., Cryo-letters, v. 10, p. 73-91, 1989. 